OPEN ACCESS

Edited by:

Zhaojun Wei,

Hefei University of Technology, China

Reviewed by:

Xiujie Jiang,

Heilongjiang Bayi Agricultural

University, China

Ruijie Liu,

Jiangnan University, China

*Correspondence:

Valter Aragão do Nascimento aragao60@hotmail.com

tThese authors have contributed equally to this work and share first

authorship

Specialty section: This article was submitted to Nutrition and Food Science Technology,

a section of the journal Frontiers in Nutrition

Received: 18 October 2021 Accepted: 29 November 2021 Published: 17 January 2022

Citation:

Siroma TK, Machate DJ, Zorgetto-Pinheiro VA, Figueiredo PS, Marcelino G, Hiane PA, Bogo D, Pott A, Cury ERJ, Guimarães RdCA,

Vilela MLB, Ferreira RdS and Nascimento VAd (2022) Polyphenols and $\omega$-3 PUFAs: Beneficial Outcomes to Obesity and Its Related Metabolic Diseases. Front. Nutr. 8:781622. doi: 10.3389/fnut.2021.781622

\section{Polyphenols and $\omega-3$ PUFAs: Beneficial Outcomes to Obesity and Its Related Metabolic Diseases}

\author{
Thais Keiko Siroma ${ }^{1 \dagger}$, David Johane Machate ${ }^{2,3 t}$, Verônica Assalin Zorgetto-Pinheiro ${ }^{1 \dagger}$, \\ Priscila Silva Figueiredo ${ }^{1}$, Gabriela Marcelino ${ }^{1}$, Priscila Aiko Hiane ${ }^{1}$, Danielle Bogo ${ }^{1}$, \\ Arnildo Pott ${ }^{4}$, Elenir Rose Jardim Cury ${ }^{1}$, Rita de Cássia Avellaneda Guimarães ${ }^{1}$, \\ Marcelo Luiz Brandão Vilela ${ }^{5}$, Rosângela dos Santos Ferreira ${ }^{6}$ and \\ Valter Aragão do Nascimento ${ }^{1,2 *}$
}

${ }^{1}$ Graduate Program in Health and Development in the Central-West Region, Federal University of Mato Grosso do Sul, Campo Grande, Brazil, ${ }^{2}$ Spectroscopy and Bioinformatics Applied Biodiversity and Health - GEBABS, Federal University of Mato Grosso do Sul, Campo Grande, Brazil, ${ }^{3}$ Graduate Program in Materials Science, Federal University of Mato Grosso do Sul, Campo Grande, Brazil, ${ }^{4}$ Graduate Program in Biotechnology and Biodiversity in the Central-West Region, Federal University of Mato Grosso do Sul, Campo Grande, Brazil, ${ }^{5}$ Medical School, Federal University of Mato Grosso do Sul, Campo Grande, Brazil, ${ }^{6}$ Graduate Program in Biotechnology, S-Inova Biotech, Catholic University Dom Bosco-UCDB, Campo Grande, Brazil

Obesity is associated with the leading causes of death in the worldwide. On the other hand, the intake of vegetables, fruits and fish is related to the reduction of obesity and other metabolic syndromes. This review aims to highlight the role of ingestion of polyphenols and omega-3 polyunsaturated fatty acids ( $\omega-3$ PUFAs) in reducing obesity and related metabolic diseases (RMDs). The consumption of vegetables, fish and by-products rich in polyphenols and $\alpha$-linolenic acid (ALA), as well as oils rich in eicosapentaenoic acid (EPA) and docosahexaenoic acid (DHA) are associated with a decrease in obesity and its RMDs in consumers. Furthermore, we discussed the adequate amount of extracts, powder, polyphenols, $\omega$-3 PUFAs administrated in animal models and human subjects, and the relevant outcomes obtained. Thus, we appeal to the research institutions and departments of the Ministries of Health in each country to develop a food education joint project to help schools, businesses and families with the aim of reducing obesity and other metabolic diseases.

Keywords: vegetable foodstuffs, fish foodstuff, metabolic diseases, $\alpha$-linolenic acid, eicosapentaenoic acid, docosahexaenoic acid

\section{INTRODUCTION}

Obesity is an abnormal accumulation of fat in cells that interferes with the maintenance of an individual's health. It is a chronic disease characterized by lower amounts of energy expenditure than ingestion, leading to body weight gain over time due to excessive increase in adipose tissue mass (1), triggering pro-inflammatory agents (2). Furthermore, obesity is linked with several diseases such as insulin resistance, systematic inflammation, diabetes mellitus (DM), hypertension, coronary heart diseases (CHD), adipocyte hypertrophy, non-alcoholic fatty liver disease (NAFLD), and others $(3,4)$. Weight can be calculated from the mathematical formula of the body mass index $(\mathrm{BMI}=$ mass/height $\times$ height), being considered overweight that can progress to obesity when $\mathrm{BMI} \geq 25$ and $\geq 30 \mathrm{~kg} / \mathrm{m}^{2}(1,2)$. In the adult population, the occurrence of obesity and overweight 
is 39 and $50 \%$, and it is mainly explained by the easy access to high-calorie foods (fast food) and sedentary lifestyle (5).

Systemic complications in obese patients are associated with increased abdominal fat, severe organ and tissue failure due to an increased pro-inflammatory cytokine storm, lipopolysaccharide and oxidative stress conditions (6). In addition, several studies have reported a decrease in obesity and its RMDs due to consumption of vegetables (leaves, seeds, nuts, fruits, vegetable oils, by-products) and fish (mainly marine fish, oils, byproducts) rich in polyphenols and $\omega-3$ PUFAs: ALA, EPA, and DHA (7-13). Furthermore, obesity and its RMDs lowering can be explained by consequence of synergistic actions of polyphenols and $\omega-3$ PUFAs improving several metabolic health pathways $(14,15)$. Due to the synergistic actions of the polyphenols and $\omega-3$ PUFAs, some products that are found, like fish and vegetables, and their by-products can potentially improve and control obesity and its RMDs as anti-glucose tolerance, anti-oxidative, anti-atherosclerosis, antiinflammation, anti-weight gain, hepato-protective, vascularprotective, cardiovascular-protective, anti-hypertension, antidiabetic effects, thus improving the human health $(13,16-$ 21). The beneficial effects of foods that contain polyphenols, ALA, EPA and DHA in their composition are summarized in Figure 1.

However, despite the reported benefit of polyphenols and $\omega-3$ PUFAs reported, obesity and its RMDs high incidence can be correlated with inadequate food intake
(22), the lower cost of unhealthy food acquisition (23) and cultural behaviors barriers (24) allied to unfavorable educational programs impact negatively on healthy food acquisition (25).

In this review, we aimed to emphasize the benefit of polyphenols and $\omega-3$ PUFAs regular intake and their sources and to propose joint actions allied to consumer's behavior change for reducing obesity and its RMDs (systematic inflammation, cardiovascular diseases, hypertension, diabetes mellitus, high insulin level, metabolic syndrome, and others).

\section{THE MAIN POLYPHENOLS SOURCES}

Vegetables, fruits, seeds, almonds, and cereals are widely known in diets and supplementations for their enormous benefits on health improving, preventing, and reducing obesity and its RMDs $(9,13)$. Health benefits are associated with the effect of bioactive substances, mainly represented by compounds with antioxidant action that are responsible for functions such as the half-life of products and their by-products (residue products as peel, pulp and seed) (12, 16, 26-30). The main polyphenol substances occurs in leaves, flowers, roots, bulbs, and rhizomes of several wild edible plants $(31,32)$. In addition, polyphenol is present in fruits as apple, grapes, pear, cherries, berries, coffee, cereals and chocolate (33), citrus, mangoes, garlic, onions (34), tomatoes, potatoes, carrots, leaves (tea), and vegetables (broccoli, cabbages, pumpkin, spinach, and lettuce). In addition, these plants (35)

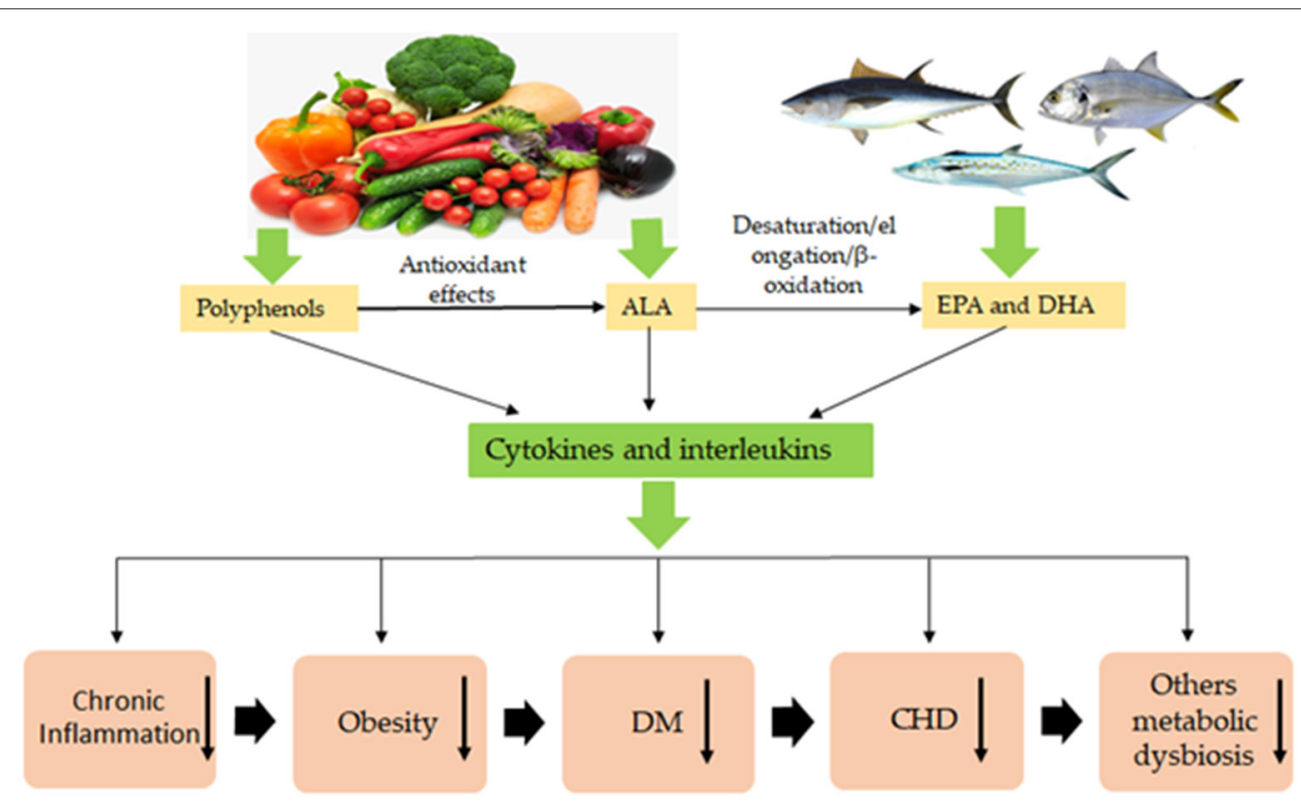

FIGURE 1 | Overview of polyphenols, $\alpha$-linolenic (ALA), eicosapentaenoic (EPA), and docosahexaenoic acids (DHA) natural sources. The polyphenol compounds obtained from vegetables are active natural antioxidants, which slow up or reduce the high speed of degradation of ALA, EPA, and DHA, quenching singlet oxygen and reacting or eliminating the free radicals, prolong the half-life of these acids during their storing and confection of food. The ingestion of polyphenols, ALA, EPA, and DHA in natural conditions prevent obesity and its related metabolic diseases, including these presented in the scheme. However, the benefit does not occur when polyphenols, ALA, EPA, and DHA are denaturated during the extraction process, storage, and food confection. Through the biosynthesis processes with the actions of enzymes, ALA is converted to EPA and DHA. The synergistic effects of polyphenols, EPA and DHA in the body promote health with preventing and reducing obesity and its related diseases for the consumers. $\downarrow$, significant decrease; DM, diabetes mellitus; CHD, cardiovascular heart diseases. 
TABLE 1 | Effects of polyphenols intake on obesity and its related metabolic diseases outcomes in animal model.

\begin{tabular}{|c|c|c|c|}
\hline Vegetable/fruit & Host & Diet & Main outcomes \\
\hline Camellia sinensis (Tea) & $\begin{array}{l}\text { Mice ICR ( } 7 \text { weeks old) male } \\
\text { obese (39) }\end{array}$ & $\begin{array}{l}\text { Six leaf drinking tea types: green, } \\
\text { black, yellow, white, oolong and post- } \\
\text { fermented ( } 13-15 \\
\mathrm{~g} / \mathrm{kg} / \text { day) for } 9 \text { weeks }\end{array}$ & $\begin{array}{l}\text { Body weight } \downarrow \\
\text { White fat } \downarrow \\
\text { Hepatic steatosis } \downarrow \\
\text { Obesity effects } \downarrow \\
\text { Anti-inflammatory } \uparrow \\
\text { IL-6 } \downarrow \\
\text { iNOS } \downarrow\end{array}$ \\
\hline & & $\begin{array}{l}\text { Grape powder extract ( } 150 \\
\mathrm{mg} / \mathrm{kg} / \text { day) for } 18 \text { weeks }\end{array}$ & $\begin{array}{l}\text { Inflammation } \downarrow \\
\text { Glucose tolerance } \downarrow\end{array}$ \\
\hline & $\begin{array}{l}\text { Wistar rats ( } 5 \text { weeks old) male obese } \\
\text { (41) }\end{array}$ & $\begin{array}{l}\text { Grape seed proanthocyanidin extract } \\
\text { ( } 25 \mathrm{mg} / \mathrm{kg} \text { body weight/day) for } 3 \\
\text { weeks }\end{array}$ & $\begin{array}{l}\text { Adipocyte number } \uparrow \\
\text { Body weight } \leftrightarrow \\
\text { Adipose tissue } \leftrightarrow \\
\text { Adipocyte size } \downarrow\end{array}$ \\
\hline $\begin{array}{l}\text { Bactris setosa (Tucum) and } \\
\text { Vitex cymosa (Tarumã) }\end{array}$ & $\begin{array}{l}\text { Mice C57BL/6J (5 weeks old) male } \\
\text { diabetic (43) }\end{array}$ & Extract $(100 \mathrm{mg} / \mathrm{kg} /$ day) for 8 weeks & $\begin{array}{l}\text { Obesity } \downarrow \\
\text { Insulin resistant } \downarrow \\
\text { Hyperinsulinemia } \downarrow\end{array}$ \\
\hline Adansonia digitata (Baobab) & $\begin{array}{l}\text { Wistar albino rats (8 weeks old) } \\
\text { diabetic (44) }\end{array}$ & $\begin{array}{l}\text { Extract ( } 200 \text { and } 400 \mathrm{mg} / \mathrm{kg} / \text { day) for } \\
6 \text { weeks }\end{array}$ & $\begin{array}{l}\text { HDL-c } \leftrightarrow \\
\text { Adipose tissue } \downarrow \\
\text { Diabetic } \downarrow\end{array}$ \\
\hline Olea europaea (Olive) & $\begin{array}{l}\text { Wistar Kyoto rats ( } 8 \text { weeks old) } \\
\text { hypertensive ( } 45)\end{array}$ & EVOO (759 mg/kg/day) for 10 weeks & $\begin{array}{l}\text { Blood pressure } \downarrow \\
\text { Cardiac hypertrophy } \downarrow \\
\text { AEF } \uparrow \\
\text { TC } \downarrow \\
\text { Pro-inflammatory } \leftrightarrow\end{array}$ \\
\hline $\begin{array}{l}\text { Solanum lycopersicum } \\
\text { (Tomato) }\end{array}$ & $\begin{array}{l}\text { Mice C57BL/6N (4 weeks old) male } \\
\text { obese (48) }\end{array}$ & $\begin{array}{l}\text { Vinegar beverage }(14 \mathrm{~mL} / \mathrm{kg} / \text { day }) \text { for } \\
6 \text { weeks }\end{array}$ & $\begin{array}{l}\text { Obesity } \downarrow \\
\text { Insulin resistance } \downarrow\end{array}$ \\
\hline Euterpe oleracea (Açai) & $\begin{array}{l}\text { Mice C57BL/6 ( } 4 \text { weeks old) male } \\
\text { obese (49) }\end{array}$ & $\begin{array}{l}\text { Seed extract ( } 300 \text { mg/kg/day) for } 12 \\
\text { weeks }\end{array}$ & $\begin{array}{l}\text { Obesity } \downarrow \\
\text { Adipose tissue } \downarrow \\
\text { NAFLD } \downarrow \\
\text { Cholesterol } \downarrow\end{array}$ \\
\hline Coffea arabica (Coffee) & $\begin{array}{l}\text { Wistar rats ( } 8-9 \text { week old) male } \\
\text { obese (50) }\end{array}$ & $\begin{array}{l}\text { Coffee extract ( } 5 \mathrm{mg} / \mathrm{kg} / \text { day) for } 8 \\
\text { weeks }\end{array}$ & $\begin{array}{l}\text { Obesity } \uparrow \\
\text { Cardiovascular } \downarrow \\
\text { Hepatic dysfunction } \downarrow \\
\text { Hypertension } \downarrow\end{array}$ \\
\hline Malus domestica (Apple) & Wistar rats male obese (51) & $\begin{array}{l}\text { Apple polyphenols }(146 \mathrm{mg} / \mathrm{kg} \text { ) for } 8 \\
\text { weeks }\end{array}$ & $\begin{array}{l}\text { Adipose tissue } \downarrow \\
\text { Glucose tolerance } \downarrow \\
\text { Obesity } \downarrow \\
\text { Fatty acid oxidation } \uparrow \\
\text { Leptin level } \downarrow\end{array}$ \\
\hline
\end{tabular}


TABLE 1 | Continued

\begin{tabular}{|c|c|c|c|}
\hline Vegetable/fruit & Host & Diet & Main outcomes \\
\hline $\begin{array}{l}\text { Tamarindus indica } \\
\text { (Tamarind) }\end{array}$ & $\begin{array}{l}\text { Sprague-Dawley rats (12 weeks old) } \\
\text { male obese (52) }\end{array}$ & $\begin{array}{l}\text { Tamarind fruit extract }(50 \mathrm{mg} / \mathrm{kg} / \text { day }) \\
\text { for } 10 \text { weeks }\end{array}$ & $\begin{array}{l}\text { Obesity } \downarrow \\
\text { Leptin } \downarrow \\
\text { Antioxidant } \uparrow \\
\text { Lipid metabolism } \leftrightarrow\end{array}$ \\
\hline $\begin{array}{l}\text { Brassica oleracea var. italica } \\
\text { (Broccoli) }\end{array}$ & $\begin{array}{l}\text { Wistar rats ( } 6-8 \text { weeks old) male } \\
\text { obese (53) }\end{array}$ & $\begin{array}{l}\text { Broccoli extract ( } 14 \text { mg/kg/day) for } 10 \\
\text { weeks }\end{array}$ & $\begin{array}{l}\text { Body weight } \downarrow \\
\text { Adipose tissue } \downarrow \\
\text { NAFLD } \downarrow\end{array}$ \\
\hline
\end{tabular}

$\uparrow$, significant increase; $\leftrightarrow$, unchanged; $\downarrow$, significant decrease; IL-6, interleukin- 6; iNOS, inducible nitic oxide synthase; TC, total cholesterol; DM, diabetes mellitus; HDL-c, high-density lipoprotein cholesterol; HNF-kB, Hepatic nuclear factor-kB; NAFLD, non-alcoholic fatty liver disease; AEF, aortic endothelial function; EVOO, extra virgin olive oil.

are natural sources of anthocyanins and stilbenes (resveratrol and piceatannol) (26), catechin, quercetin, kaempferol (27), umbelliferone, epicatechin, phenolic acids (gallic, ellagic, chlorogenic, caffeic, and coumaric) (34), hydroxytyrosol, tyrosol (35), curcumin, rutin, chrysin (36), myricetin, isorhamnetin, hesperidin, narirutin, naringin, apigenin, luteolin, pelargonidin, cyanidin, delphinidin, genistein, daidzein (37), ellagitannins, and others (38). The effects of vegetables, fruits and polyphenols on obesity and its RMDs in animal models are summarized in Table 1.

Several studies have been reported on obesity and its RMDs lowering using different extracts from leaves, flowers, fruits, seeds, rhizome, powder, and EVOO obtained from wild and cultivated plants regularly administrated at $3 \mathrm{mg} / \mathrm{kg} /$ day to $23 \mathrm{~g} / \mathrm{kg} /$ day for 3-24 weeks to animal models (Table 1). Controversially, other studies using dairy dose administrated from the green tea polyphenols $(10-29 \mathrm{mg} / \mathrm{kg}$ ), catechin (200 and $400 \mathrm{mg} / \mathrm{kg}$ ) (54), caffeic acid, quercetin (2 or $4 \%$ ) (55), and proanthocyanin grape seed extract (4 $\mathrm{g} / \mathrm{kg} / 2$ weeks) (56), reported liver, kidney and gastrointestinal toxicity, which can evolve to inflammation or death, due to high reactive oxygen species and oxidative stress formation. In addition, some studies with humans administered polyphenols showed the same results that can be explained by genetic effects, ethnicity, gender, eating habits, length of time, lifestyle, and others (57). Therefore, the reported high health benefits of regular consumption of polyphenol-rich plants and vegetables are widely recommended to prevent, control and reduce obesity and RMDs in humans and animals (57). Likewise, the health benefit for humans with obesity, that administered vegetables, fruits and polyphenols for 4-12 weeks are summarized in Table 2.

\section{THE MAIN $\omega-3$ PUFAs SOURCES}

The main sources of $\omega-3$ PUFAs, including ALA, EPA and DHA are green leafy vegetables, seaweed, seeds, nuts, vegetable oils, fish and fish oils (68-77). The vegetable and fish origin $\omega-3$ PUFAs are summarized in Table 3.

ALA is abundantly obtained in vegetable foodstuff and microalgae (7-94\%) followed by vegetable oils (6-58\%) and freshwater fish (1-4\%) $(69,70,73-77)$. While EPA and DHA are the majority in fish oil (7-13\% and 9-18\%), marine fish (3$6 \%$ and $13-33 \%)$, microalgae (13-31\% and $2-14 \%)$, macroalgae $(3-27 \%$ and $1-5 \%)$, and fish of freshwater $(0.4-3 \%$ and $2-9 \%)$ $(69,71-74,76)$.

The $\omega-3$ PUFAs and $\omega-6$ PUFAs are essential fatty acids (cannot be biosynthesized by the mammalian body, including humans) are required from the diet $(78,79)$. In the human body, through to physiology mechanism reactions, which ALA is converted to long chain PUFAs (LC-PUFAs, fatty acids $\leq$ C20) and very-long-chain fatty acids (VLCFAs, fatty acids $\geq$ C22) $(78,79)$, which the ALA converted rate to EPA and DHA is $5-8 \%(80)$. The biosynthetic process of VLCFAs production, starting by ALA from the diet to the bloodstream is illustrated in Figure 2.

When consumed and going through several physiological reactions in the body, EPA and DHA present positive effects such as anti-inflammation, vasodilation, bronchodilation and antiplatelet aggregation (78). Beyond, both acids are correlated with cyclooxygenase, prostacyclin, thromboxane, leukotrienes, lipoxins, and resolvins, which play a crucial role in several beneficial physiologic actions $(78,79,81)$. The consumption of an $\omega-3$ PUFAs-rich balanced diet, including ALA, EPA, and DHA is correlated with health-improving and decreasing and or preventing obesity and its RMDs, such as adipose tissue fat accumulation, insulin resistance, inflammation, hypertension, atherosclerosis, CVD, CHD, and $\operatorname{DM}(4,78,79)$.

However, due to the presence of double bond in carbon3 of methyl end ( $\omega-3)$, including ALA, EPA, and DHA, $\omega-3$ PUFAs family is susceptible to oxidation by light, temperature, metal ions and microorganism degradation during oil extraction and storage by autoxidation reactions (photochemical and photosensitized oxidation) with 4Hydroxy-2-hexenal production $(82,83)$. These reactions result in enzymatic oxidation with increase the production of $\mathrm{E}$ series resolvins from EPA, and D-series Resolvins (DHA), prostaglandins, thromboxanes, leukotrienes, epoxy products $(84,85)$. Besides, the $\omega-3$ PUFAs decrease in amount during food confections by thermal processing, while in inversely proportion occurs the increasing of degradation and hazard oxidized substances that damage cell membranes $(86,87)$. The oxidation products are higher in fried, followed by roasted, and boiled foods, which present the same proportion of oxidative products when compared to raw food $(88,89)$. 
TABLE 2 | Effects of polyphenols from vegetables and fruits intake on obesity and its related metabolic diseases outcomes in human subjects.

\begin{tabular}{|c|c|c|c|}
\hline Vegetable/fruit & Host & Diet & Main outcomes \\
\hline Vitis vinifera (Grape) & $\begin{array}{l}\text { Men and women (20-60 years old) } \\
\text { obese (58) }\end{array}$ & $\begin{array}{l}\text { Grape powder (4,600 mg/day) for } 9 \\
\text { weeks }\end{array}$ & $\begin{array}{l}\text { LDL-C } \downarrow \\
\mathrm{IL}-1 \beta \uparrow \\
\mathrm{IL}-6 \uparrow\end{array}$ \\
\hline $\begin{array}{l}\text { Vaccinium macrocarpon } \\
\text { (Cranberry) }\end{array}$ & $\begin{array}{l}\text { Men and women (30-70 years old) } \\
\text { obese (59) }\end{array}$ & $\begin{array}{l}\text { Cranberry extract beverage }(450 \\
\mathrm{mL} / \text { day) for } 8 \text { weeks }\end{array}$ & $\begin{array}{l}\text { Glucose regulation } \uparrow \\
\text { HDL-C } \uparrow \\
\text { Serum insulin } \downarrow \\
\text { CVD } \downarrow \\
\text { Inflammation } \downarrow\end{array}$ \\
\hline Mangifera indica (Mango) & Women (25-45 years old) obese & $\begin{array}{l}\text { Peel powder of mango ( } 1 \mathrm{~g} / 2 \times \text { day }) \\
\text { for } 12 \text { weeks }\end{array}$ & $\begin{array}{l}\text { LDL-C } \downarrow \\
\text { Triglyceride } \downarrow \\
\text { HDL-C } \uparrow\end{array}$ \\
\hline Olea europaea (Olive) & Women (27 years old) obese (60) & EVOO (25 mL/day) for 9 weeks & $\begin{array}{l}\text { HDL-C } \uparrow \\
\text { BW } \downarrow \\
\text { Blood pressure } \downarrow \\
\text { Inflammation } \downarrow \\
\text { Oxidative stress } \downarrow \\
\text { Dyslipidemia } \downarrow\end{array}$ \\
\hline $\begin{array}{l}\text { Citrullus lanatus } \\
\text { (Watermelon) }\end{array}$ & $\begin{array}{l}\text { Men and women (18-55 years old) } \\
\text { obese (61) }\end{array}$ & $\begin{array}{l}\text { Watermelon fruit }(2 \text { cups }=152 \\
\text { g/day) for } 4 \text { weeks }\end{array}$ & $\begin{array}{l}\text { BW } \downarrow \\
\text { Blood pressure } \downarrow \\
\text { CVD } \downarrow \\
\text { Blood lipid profile } \uparrow \\
\text { Antioxidant status } \uparrow\end{array}$ \\
\hline $\begin{array}{l}\text { Ilex paraguariensis (Yerba } \\
\text { mate) }\end{array}$ & $\begin{array}{l}\text { Men and women (35-60 years old) } \\
\text { obese (62) }\end{array}$ & $\begin{array}{l}\text { Yerba mate tea }(500 \mathrm{~mL} / 2 \times \text { day }) \text { for } \\
4 \text { weeks }\end{array}$ & $\begin{array}{l}\text { Serum level } \uparrow \\
\text { HDL-c } \uparrow \\
\text { Atherosclerotic } \\
\text { diseases protection } \uparrow\end{array}$ \\
\hline $\begin{array}{l}\text { Lippia citriodora and } \\
\text { Hibiscus sabdarifa }\end{array}$ & Women (36-69 years old) obese (63) & $\begin{array}{l}\text { Combination polyphenol extract (500 } \\
\text { mg/day) for } 8 \text { weeks }\end{array}$ & $\begin{array}{l}\text { BW } \uparrow \\
\text { Fat metabolism } \uparrow \\
\text { Adiposity } \uparrow\end{array}$ \\
\hline Citrus sinensis (Orange) & Women (29-43 years old) obese (64) & $\begin{array}{l}\text { Orange juice ( } 250 \mathrm{~mL} / \times \text { day) for } 12 \\
\text { weeks }\end{array}$ & $\begin{array}{l}\text { Total cholesterol } \uparrow \\
\text { LDL-c } \uparrow \\
\text { Inflammation } \downarrow\end{array}$ \\
\hline $\begin{array}{l}\text { Fragaria ananassa } \\
\text { (Strawberry) }\end{array}$ & $\begin{array}{l}\text { Men and women ( } 20-50 \text { years old }) \\
\text { obese (65) }\end{array}$ & $\begin{array}{l}\text { Strawberry powder ( } 2 \text { servings }=160 \\
\text { g/day) for } 7 \text { weeks }\end{array}$ & $\begin{array}{l}\text { CVD } \uparrow \\
\text { Stroke } \uparrow \\
\text { Diabetes } \uparrow\end{array}$ \\
\hline $\begin{array}{l}\text { Cinnamomum verum } \\
\text { (Cinnamon) }\end{array}$ & $\begin{array}{l}\text { Men and women ( } 40-50 \text { years old) } \\
\text { obese (66) }\end{array}$ & $\begin{array}{l}\text { Cinnamon extract }(250 \text { mg/ } 2 \times \text { day }) \\
\text { for } 12 \text { weeks }\end{array}$ & $\begin{array}{l}\text { Diabetes } \uparrow \\
\text { CVD } \uparrow \\
\text { Free radical } \uparrow\end{array}$ \\
\hline $\begin{array}{l}\text { Helianthus annuus } \\
\text { (Sunflower) }\end{array}$ & $\begin{array}{l}\text { Men and women (18-65 years old) } \\
\text { obese (67) }\end{array}$ & $\begin{array}{l}\text { Sunflower seed extract ( } 500 \text { mg/day) } \\
\text { for } 12 \text { weeks }\end{array}$ & $\begin{array}{l}\mathrm{BW} \uparrow \\
\mathrm{BMI} \uparrow \\
\text { Cholesterol } \uparrow \\
\text { Lipid metabolism } \uparrow\end{array}$ \\
\hline
\end{tabular}

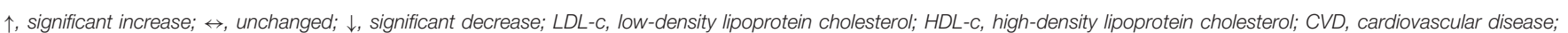

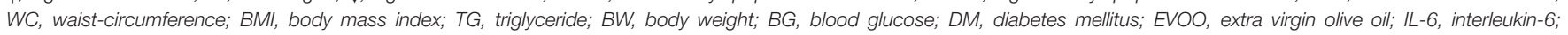

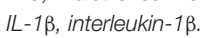

The frying and roasting food confections release the most oxidative products (4(RS)-4-F4t-NeuroP, 4-Hydroxy-2hexenal production, and others), which are correlated with obesity, CVD, inflammation, hypertension, and others diseases $(82,83)$.

Therefore, the application of natural antioxidant compounds such as carotenoids, tocopherols, tocotrienols, phytostanols, phytosterols, and ascorbic acid are recommended due to their symbiotic and synergistic interactions decrease oxidation and thermal degradation, prolonging the shelf life of $\omega-3$ PUFAs during the period of storage (90-92).

\section{DIETARY EPA AND DHA DIETS BENEFITS ON OBESITY AND ITS RMDs}

Diets consumption rich in vegetables and fish and their byproducts are correlated with reducing obesity and its RDMs effects for presenting ALA, EPA, and DHA in their composition $(4,78,79)$, and for animal models are summarizing in Table 4.

Obesity and its reduction in RMDs have been reported in animal studies that consumed for 3-20 weeks EPA from vegetable/fruit and cafeteria diets $(33 \mathrm{mg} / \mathrm{g} /$ day to 1,000 $\mathrm{mg} / \mathrm{kg} /$ day), EPA mixed with DHA (2-5,300 $\mathrm{mg} / \mathrm{g}$ and 3-9,400 $\mathrm{mg} / \mathrm{g} /$ day), ALA (92 g/kg/day), $\omega-3 / \omega-6$ (1:1), and linoleic acid 
TABLE 3 | Contents of n-3 PUFAs and their vegetable and fish sources used in human food.

\begin{tabular}{|c|c|c|c|c|c|}
\hline \multirow[t]{2}{*}{ Source } & \multirow[t]{2}{*}{ Food } & \multicolumn{3}{|c|}{$\omega-3$ PUFAs (\%) } & \multirow[t]{2}{*}{ References } \\
\hline & & ALA & EPA & DHA & \\
\hline \multirow[t]{5}{*}{ Vegetable } & Moringa oleifera (flower, pod, leaf) & $18.8-54.3$ & 0 & 0 & (68) \\
\hline & Brassica spp. & $7.0-20.0$ & 0 & 0 & (69) \\
\hline & Lactuca sativa (baby-leaf) & $44.0-55.0$ & 0 & 0 & $(77)$ \\
\hline & Solanum spp. (leaf) & $50.0-54.0$ & 0 & 0 & $(70)$ \\
\hline & Flax and chia seed & 22.8 & 0 & 0 & (69) \\
\hline \multirow[t]{3}{*}{ Vegetable oil } & Linum usitatissimum (seed) & $53.0-58.3$ & 0 & 0 & (69) \\
\hline & Brassica spp. (seed) & $6.8-20.2$ & 0 & 0 & $(69,75)$ \\
\hline & Glycine max (seed) & $6.0-15.9$ & 0 & 0 & (69) \\
\hline \multirow[t]{2}{*}{ Macroalgae } & Phaeophyta spp. & 0 & $6.6-14.4$ & $0.8-1.5$ & (71) \\
\hline & Rhodophyta spp. & 0 & $2.9-27.3$ & 4.9 & $(71)$ \\
\hline \multirow[t]{7}{*}{ Microalgae } & Chroomonas mesostigmatica & 60.3 & 30.5 & 1.7 & $(72)$ \\
\hline & Guillardia theta & 56.7 & 14.9 & 3.0 & $(72)$ \\
\hline & Hemiselmis sp. & 53.2 & 21.2 & 5.1 & $(72)$ \\
\hline & Proteomonas sulcata & 58.5 & 12.7 & 12.6 & $(72)$ \\
\hline & Rhodomonas salina & 48.8 & 17.2 & 11.2 & $(72)$ \\
\hline & Storeatula major & 41.9 & 16.0 & 10.0 & $(72)$ \\
\hline & Teleaulax spp. & $43.3-46.2$ & $23.6-26.0$ & $12.7-14.3$ & $(72)$ \\
\hline \multirow[t]{6}{*}{ Fish of freshwater } & Pimelodus spp. & $1.3-3.9$ & $0.4-1.3$ & $1.9-8.2$ & (73) \\
\hline & Ageneiosus brevifilis (Palmito) & 0.9 & 0.7 & 8.7 & (73) \\
\hline & Aspius aspius (Asp) & 2.2 & 2.6 & 5.2 & (74) \\
\hline & Barbus barbus (Common brarbel) & 3.4 & 2.9 & 5.6 & $(74)$ \\
\hline & Acipenser ruthenus (Sterlet) & 4.3 & 2.9 & 3.8 & $(74)$ \\
\hline & Esox lucius (Northern pike) & 2.6 & 1.6 & 7.6 & $(74)$ \\
\hline \multirow[t]{3}{*}{ Fish of marine water } & Caranx hippos (Crevalle jack) & 0 & 3.1 & 17.6 & $(74)$ \\
\hline & Thunnus thynnus (AB tuna) & 0 & 4.8 & 32.5 & $(76)$ \\
\hline & Scomberomorus maculatus (AS mackerel) & 0 & 5.6 & 12.6 & $(76)$ \\
\hline \multirow[t]{4}{*}{ Fish oil } & Sardine pilchardus (sardine) & 0 & 10.1 & 10.7 & (69) \\
\hline & Brevoortia tyrannus (menhaden) & 0 & 13.2 & 8.6 & (69) \\
\hline & Salmon spp. (salmon) & 0 & 13.0 & 18.2 & (69) \\
\hline & Gadus morhua (cod liver) & 0 & 6.9 & 11.0 & (69) \\
\hline
\end{tabular}

PUFAs, Polyunsaturated fatty acids; ALA, $\alpha$-linolenic acid; EPA, eicosapentaenoic acid; DHA, docosahexaenoic acid.

(LA) plus ALA (2:1) $(93,94,99,100,102-104)$. These positive effects observed are correlated with $\omega-3$ PUFAs that improve and repair several organs for normal function linked to hepatic organ for better lipogenesis, insulin resistance, lipid homeostasis, adipocytes function, $\beta$-oxidation, and increasing leptin and adiponectin production, pro-inflammatory mediators reducing from LA and arachidonic (AA) acids $(78,79,81)$. However, some studies reported a discrepancy effect of $\omega-3$ PUFAs to diabetes, cholesterol, plasma glucose (105), overweight and obesity (106), inflammatory cytokines (107), cardiovascular diseases, and others (108). These $\omega-3$ PUFAs fail results can be associated with its preparation, doses quantity, administration duration period, subject target, statistics, and other factors (109, 110). Therefore, $\omega-3$ PUFAs regular consumption is recommended due to numerous studies that demonstrated strong positive effects against several metabolic diseases in animal models and human subjects, as summarized in Table 5.
Furthermore, lowering obesity and its RMDs were observed for human subjects daily administered $2 \times 2 \mathrm{~g}$ of flaxseed powder, as well as in proportion of 4:1 and 2:1 of LA and ALA for 1 and 2 weeks $(111,112)$, EPA daily dosed $3 \times 300 \mathrm{mg}$ or $3 \times 600 \mathrm{mg}$, dose of 1,800 mg during 12 weeks and 5 years (114-116), and doses of EPA and DHA during 8-25 weeks in proportions of $1: 1.5,1.5: 1$, and $1: 4(117-119)$.

\section{POLYPHENOLS AND $\omega-3$ PUFAS MECHANISMS ON OBESITY AND ITS RMDs}

Increasing of obesity and its RMDs are already observed from childhood to elderly individuals and have become a public health problem in modern society $(120,121)$. A practical alternative against obesity and its RDMs in humans can be associated 


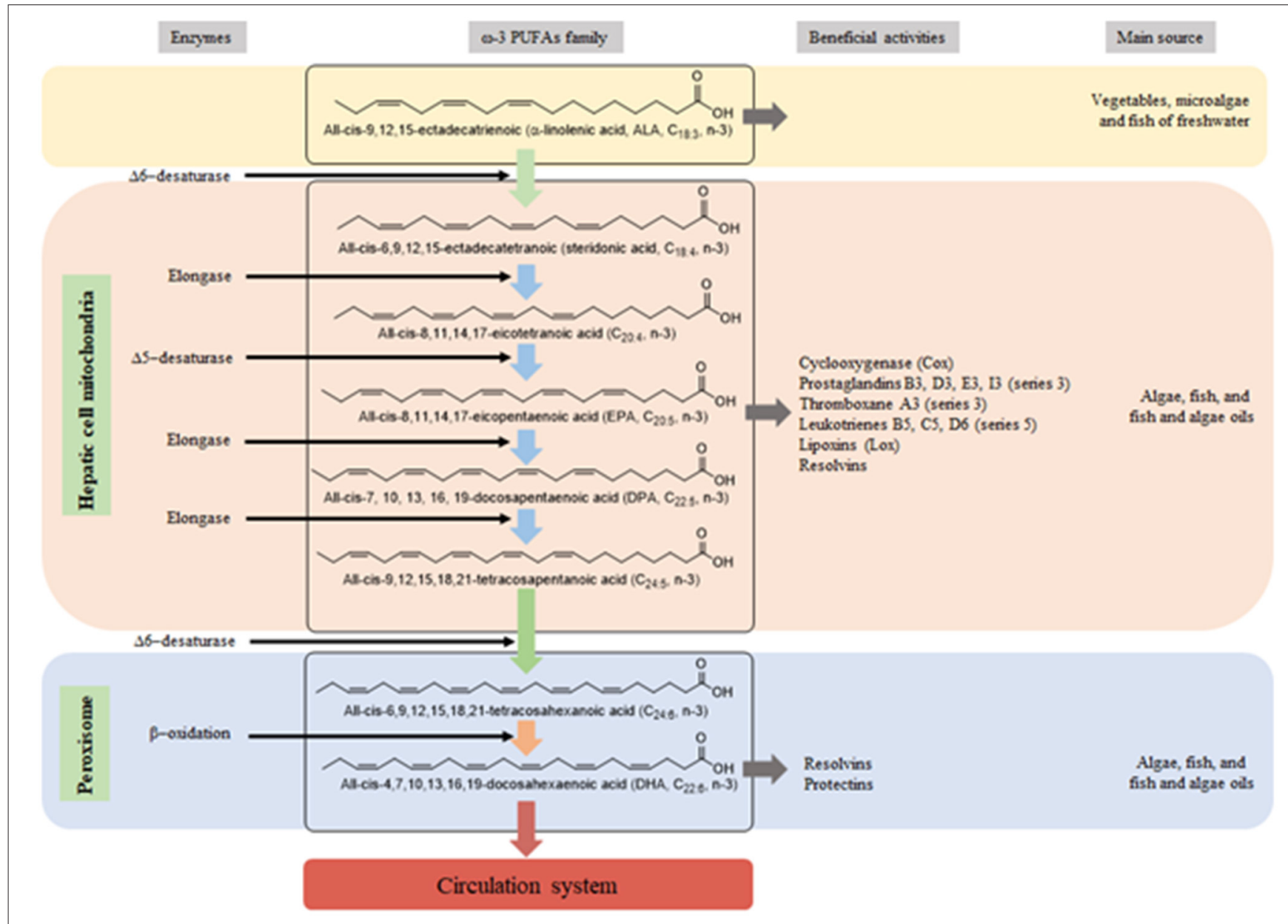

FIGURE 2 | Biosynthesis pathway of very-long-chain polyunsaturated fatty acids (LC-PUFAs) and very long-chain fatty acids (VLCFAs) in the human body starting by the $\alpha$-linolenic acid (ALA) obtained from the diet. The LC-PUFAs and VLCFAs biosynthesis process occurs in hepatic cell mitochondria and peroxisome. These acids reach the bloodstream, which are conducted to different body parts for health benefits.

with diet-rich in polyphenols and $\omega-3$ PUFAs in composition, including their by-products (112). In the body, polyphenols and $\omega-3$ PUFAs (DHA and EPA) physiologically act protecting and inhibiting cascade inflammatory reaction processes that can evolve into obesity, diabetes, CVD, hypercholesterolemia, and others metabolic diseases $(122,123)$. Thus, mechanisms that polyphenols and $\omega-3$ PUFAs are involved in the body, which are crucial to prevent several metabolic diseases, which can be used as adjuvant therapy, are summarized in Figure 3.

In the liver, PUFAs are metabolized and converted into prostaglandins (PGE2) and leukotrienes, which reach the inflammation site being converted into lipoxins, resolvins, protectins, and maresins, which will stimulate type 2 macrophages more so than the type 1 kind, leading to the production of anti- inflammatory interleukins (124, 125). Likewise, polyphenols are absorbed in the intestine after being hydrolyzed by intestine enzymes and the host's microbiota (126). Then, the resulting molecules can interact with free radicals and inhibit enzymes involved in the AA pathway, modulating the inflammatory response and blocking the AA pathway (14). Besides that, endothelial cells are also being stimulated by both products from polyphenols and $\omega-3$ PUFAs metabolization to produce $\mathrm{NO}$ and $\mathrm{H}_{2} \mathrm{~S}$ in the first case, which will aid the resolution of the inflammatory situation and the tissue regeneration, or trigger signaling cascades by interacting with cell membrane receptors such as vascular endothelial growth factor (VEGF) or blocking p-AKT, NF- $\kappa$, and MMP-9 activities $(122,127)$.

The mechanisms involved in balancing the inflammatory process are the change of the phospholipid fatty acid composition of the cell membrane, inhibition of the NF- $\kappa \beta$ activation, thus reducing the expression of pro-inflammatory genes and production of resolving mediators by macrophages (122).

\section{CONSUMER BEHAVIOR CHANGES ON OBESITY AND ITS RMDS}

Choosing daily healthy food type intake is the chief component and managed by humans to improve their own and all 
TABLE 4 | Effects of EPA and DHA intake on obesity and related metabolic diseases outcomes in animal models.

\begin{tabular}{|c|c|c|}
\hline Host & Diet & Main outcome \\
\hline Rats Wistar (6 weeks old) overweight male (93) & $\begin{array}{l}\text { EPA ethyl ester of cafeteria diets }(1,000 \\
\mathrm{mg} / \mathrm{kg} / \text { day) for } 5 \text { weeks }\end{array}$ & $\begin{array}{l}\text { Body weight } \downarrow \\
\text { Adipose tissue } \downarrow \\
\text { Inflammation } \downarrow \\
\text { Insulin resistance } \downarrow\end{array}$ \\
\hline Rats JCR:LA-cp (3 weeks old) obese male (94) & $\begin{array}{l}\mathrm{EPA}(5,300 \mathrm{mg})+\mathrm{DHA}(9,400 \mathrm{mg} / \mathrm{kg} / \text { day }) \text { for } 3 \\
\text { weeks; }\end{array}$ & $\begin{array}{l}\text { Body weight } \downarrow \\
\text { TG } \downarrow \\
\text { LDL-C } \downarrow \\
\text { HDL-C } \uparrow\end{array}$ \\
\hline $\begin{array}{l}\text { Rats Wistar (8 weeks old) liver triacylglycerol } \\
\text { and insulin resistance male (95) }\end{array}$ & $\begin{array}{l}\text { Fish oil: EPA (328 mg) + DHA ( } 440 \text { mg)/kg/day) } \\
\text { for } 4 \text { weeks }\end{array}$ & $\begin{array}{l}\text { Hepatic } \beta \text {-oxidation } \uparrow \\
\text { Hepatic lipogenesis } \downarrow\end{array}$ \\
\hline $\begin{array}{l}\text { Mice C57BL/6J (5 weeks old) metabolic } \\
\text { syndrome male (96) }\end{array}$ & $\begin{array}{l}\text { Fish and algal oils EPA + DHA oral } \\
\text { administrated for } 11 \text { weeks } \\
\text { 1. EPA }(0.03 \mathrm{mg})+\mathrm{DHA}(0.06 \mathrm{mg}) / \mathrm{kg} / \text { day } \\
\text { 2. EPA }(0.05 \mathrm{mg})+\mathrm{DHA}(0.05 \mathrm{mg}) / \mathrm{kg} / \text { day } \\
\text { 3. EPA }(0.06 \mathrm{mg})+\mathrm{DHA}(0.03 \mathrm{mg}) / \mathrm{kg} / \text { day }\end{array}$ & $\begin{array}{l}\text { Body weight } \downarrow \\
\text { LDL-C } \downarrow \\
\text { Steatosis } \downarrow \\
\text { Inflammation } \downarrow \\
\text { TG } \downarrow \\
\text { TC } \downarrow\end{array}$ \\
\hline $\begin{array}{l}\text { Mice C57BL/KsJ-leprdb/leprdb (7 weeks old) } \\
\text { obese and DM male (97) }\end{array}$ & $\mathrm{EPA}(15 \mathrm{mg})+\mathrm{DHA}(8 \mathrm{mg}) / \mathrm{g} /$ day $)$ for 6 weeks & Adipose tissue $\downarrow$ \\
\hline Mice Elovl2 -/- weight gain (98) & $\begin{array}{l}\text { Low sucrose + DHA (10,000 mg/kg/day) for } 4 \\
\text { weeks }\end{array}$ & $\mathrm{BW} \downarrow$ \\
\hline Mice Elovl2 -/- or Wilde-type weight gain (98) & $\begin{array}{l}\text { High sucrose + DHA (10,000 mg/kg/day) for } 4 \\
\text { weeks }\end{array}$ & $\mathrm{BW} \uparrow$ \\
\hline Mice C57BL/6J (6 weeks old) obese male (99) & $\begin{array}{l}\text { HFD-EPA }(2 \mathrm{mg})+\mathrm{DHA}(5 \mathrm{mg}) / \mathrm{g} / \text { day for } 8 \\
\text { weeks }\end{array}$ & $\begin{array}{l}\text { Adipose tissue } \downarrow \\
\text { Inflammation } \downarrow\end{array}$ \\
\hline $\begin{array}{l}\text { Rats Sprague-Dawley ( } 3 \text { weeks old) obese and } \\
\text { insulin resistance male (100) }\end{array}$ & $\begin{array}{l}\omega-3+\omega-6 \text { PUFAs }(83,000+83,000 \\
\mathrm{mg} / \mathrm{kg} / \text { day }) \text { for } 16 \text { weeks }\end{array}$ & $\begin{array}{l}\text { Blood lipid } \downarrow \\
\text { Body and visceral fat } \downarrow \\
\text { Glucose tolerance and insulin } \\
\text { sensitivity } \uparrow \\
\text { Pro-inflammatory cytokines } \downarrow\end{array}$ \\
\hline $\begin{array}{l}\text { Mice C57BL/6J (3 weeks old) metabolic } \\
\text { syndrome male (101) }\end{array}$ & ALA (92 mg/kg/day) for 10 weeks & $\begin{array}{l}\text { Positive hepatic expression } \uparrow \\
\text { Metabolic parameters } \uparrow \\
\text { Glycemic parameters } \uparrow\end{array}$ \\
\hline $\begin{array}{l}\text { Rats Sprague-Dawley ( } 3 \text { weeks old) } \\
\text { inflammation bowel male (102) }\end{array}$ & $L A+A L A(2 g+1 g / 100$ g/day) for 12 weeks & $\begin{array}{l}\text { Colonic inflammation } \downarrow \\
\text { Colon length } \uparrow \\
\text { Pro-inflammatory cytokines } \downarrow \\
\text { Colon } \omega \text {-3 PUFAs } \uparrow\end{array}$ \\
\hline $\begin{array}{l}\text { Rats Wistar ( } 3 \text { weeks old) metabolic syndrome } \\
\text { male (103) }\end{array}$ & $\begin{array}{l}\text { Supplement marine algae } \\
\text { Phaeodactylum tricornutum (EPA }=33 \\
\text { mg/g/day) for } 8 \text { weeks }\end{array}$ & $\begin{array}{l}\text { BW } \downarrow \\
\text { Fat mass } \downarrow \\
\text { Inflammation } \downarrow \\
\text { Insulin resistance } \downarrow \\
\text { TC } \downarrow \\
\text { Triacylglycerol } \downarrow \\
\text { Leptin } \downarrow\end{array}$ \\
\hline $\begin{array}{l}\text { Mice C57BL/6J (6 weeks old) hepatic steatosis } \\
\text { and metabolic syndrome male (104) }\end{array}$ & $\begin{array}{l}\text { Fruits and vegetable powder mixed }(E P A=340 \\
\mathrm{mg} / \mathrm{g}) \text { for } 20 \text { weeks }\end{array}$ & $\begin{array}{l}\text { Weight body } \downarrow \\
\text { Hepatic steatosis } \downarrow \\
\text { Inflammation } \downarrow \\
\text { Blood and liver ceramides } \downarrow\end{array}$ \\
\hline
\end{tabular}

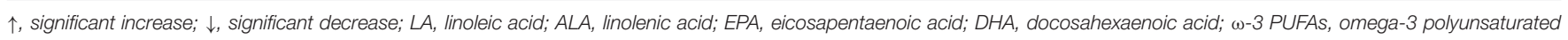

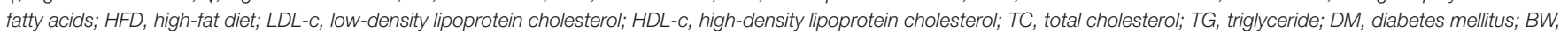
body weight.

family healthy lifestyle (128). Among the several factors of healthy lifestyle or prevalence of obesity and its RMDs can be associated with regular or irregularly and healthy or unhealthy daily food consumed in each meal $(22,129)$. In addition, it may also be associated with the lower purchase price of unhealthy foods on the market compared with healthy ones, whose edible parts (leaves, peel, flesh, seeds, and others) are wasted in homes, restaurants and other food enterprises due to their lack of nutritional knowledge $(130,131)$. In addition, also it is known that refined sugar is often always added to edible vegetables, fruits, natural juices and other by-products and other beverages, which can be associated with obesity, overweight, CVD, and other metabolic diseases prevalence (132). 
TABLE 5 | Effects of EPA and DHA intake on obesity and its related metabolic diseases outcomes in human subjects.

\begin{tabular}{|c|c|c|}
\hline Host & Diet & Main outcome \\
\hline Men and women DM (57-68 years old) (111) & $\begin{array}{l}\text { Flaxseed powder } \omega \text {-3 PUFAs-ALA-rich }(5 \mathrm{~g} / 2 \\
\times \text { day) for } 4 \text { weeks }\end{array}$ & $\begin{array}{l}\text { HDL-C } \uparrow \\
\text { LDL-C } \downarrow \\
\text { TC } \downarrow \\
\text { Triglycerides } \downarrow\end{array}$ \\
\hline $\begin{array}{l}\text { Men and women hypercholesterolemic (36-65 } \\
\text { years old) (112) }\end{array}$ & LA $(20$ or $40 \mathrm{~g})+\mathrm{ALA}(10 \mathrm{~g}) /$ day for 1 week & $\begin{array}{l}\text { TC } \downarrow \\
\text { LDL-C } \downarrow \\
\text { Triglycerides } \downarrow \\
\text { CVD risk } \downarrow \\
\text { Inflammation } \downarrow\end{array}$ \\
\hline Men and women CVD ( $\geq 30$ years old) (113) & $\begin{array}{l}\text { EPA }(600 \mathrm{~g})+\mathrm{DHA}(1,500 \mathrm{mg}) / \text { day from } \\
\text { microalgae Schizochytrium sp. oil for } 4 \text { weeks }\end{array}$ & $\begin{array}{l}\text { LDL-c } \uparrow \\
\text { HDL-c } \uparrow \\
\text { LDL/HDL } \leftrightarrow \\
\text { CVD } \leftrightarrow\end{array}$ \\
\hline $\begin{array}{l}\text { Men and women obese and DM ( } \geq 85 \text { years } \\
\text { old) (114) }\end{array}$ & EPA $(1,800 \mathrm{mg} /$ day $)$ in capsule for 12 weeks & $\begin{array}{l}\text { BMI } \downarrow \\
\text { Insulin } \downarrow \\
\text { LDL-C } \downarrow \\
\text { HDL-C } \downarrow \\
\text { TC } \downarrow \\
\text { TG } \downarrow\end{array}$ \\
\hline $\begin{array}{l}\text { Men and women major coronary artery disease } \\
\text { (mean } 62 \text { years old) (115) }\end{array}$ & EPA $(600 \mathrm{mg} / 3 \times$ day) for 5 years & $\begin{array}{l}\text { DM } \downarrow \\
\text { Hypertension } \downarrow \\
\text { LDL-C } \downarrow \\
\text { HDL-C } \downarrow \\
\text { TG } \downarrow\end{array}$ \\
\hline $\begin{array}{l}\text { Men and women hypercholesterolemic } \geq 6.5 \\
\mathrm{mmol} / \mathrm{L} \text { ( } \geq 40 \text { years old) (116) }\end{array}$ & EPA (300 mg/3 $\times$ day) capsuled for 5 years & $\begin{array}{l}\text { Stroke } \downarrow \\
\text { LDL-C } \uparrow \\
\text { HDL-C } \downarrow \\
\text { TG } \downarrow\end{array}$ \\
\hline $\begin{array}{l}\text { Women (8-20 weeks gestation) obese }(\geq 27 \\
\text { years old) (117) }\end{array}$ & $\begin{array}{l}\mathrm{EPA}(800 \mathrm{mg})+\mathrm{DHA}(1,200 \mathrm{mg}) / \text { day for } 25 \\
\text { weeks }\end{array}$ & Inflammation $\downarrow$ \\
\hline $\begin{array}{l}\text { Men and women (28-60 years old) } \\
\text { hypertensive and/or diabetic (118) }\end{array}$ & $\begin{array}{l}\text { EPA }(300 \mathrm{mg})+\mathrm{DHA}(200 \mathrm{mg}) / \text { day capsuled } \\
\text { for } 8 \text { weeks }\end{array}$ & $\begin{array}{l}\text { Inflammation } \leftrightarrow \\
\text { TC } \leftrightarrow \\
\text { TG } \downarrow \\
\text { BG } \downarrow\end{array}$ \\
\hline $\begin{array}{l}\text { Women pre-menopausal elevated triglyceride } \\
\text { (<18 or }>40 \text { years old). (119) }\end{array}$ & $\begin{array}{l}\text { Tuna oil DHA (135 mg) + EPA (35 mg)/day for } 8 \\
\text { weeks }\end{array}$ & $\begin{array}{l}\text { TG } \downarrow \\
\text { Blood pressure } \downarrow \\
\text { HDL-DHA } \uparrow \\
\text { LDL-DHA } \downarrow \\
\text { VLDL-TG } \downarrow\end{array}$ \\
\hline
\end{tabular}

$\uparrow$, significant increase; $\downarrow$, significant decrease; $\leftrightarrow$, unchanged; BMI, body mass index; BG, blood glucose; EPA, eicosapentaenoic acid; DHA, docosahexaenoic acid; LDL-C, low-density lipoprotein cholesterol; HDL-c, high-density lipoprotein cholesterol; VLDL, very low-density lipoprotein; TC, total cholesterol; TG, triglyceride; DM, diabetes mellitus; CVD, cardiovascular diseases; ALA, $\alpha$-linolenic acid; LA, linolenic acid; $\omega$-3 PUFAs, omega-3 polyunsaturated fatty acids.

Thereby, Figure 4 summarizes food types that improve healthy life (green line), which oil rich in $\omega$-3 PUFAs, oleic acid and short-chain fatty acid are widely recommended (4). Daily at least $400 \mathrm{mg}$ of natural and/or native fruits and vegetables (133), while weekly $3 \times 150 \mathrm{~g}$ of fish are recommended (134). Furthermore, fruits, vegetables and fishes are natural sources of macro- and microelements, vitamins, resistant nutrients, free sugars and fibers, which play a crucial role in microbiota balance, satiety, gut health and act as antioxidants in the body, improving and/or impeding obesity and others prevalent metabolic diseases (135-137).

Paradoxically, nowadays, meals rich in vegetables and fruits are associated with poor and traditional peoples, while meat and sweetened ones are associated with rich and modern life $(24,138,139)$. The consumption of foods marked by the red line (Figure 4) must be reduced, because they are sweetened and fatted, including long-chain saturated fatty acids (mainly myristic and palmitic acids), $\omega-6$ PUFAs and industrialized transfatty acids present high amounts of calories in their composition, which are primarily associated with obesity and its prevalent RDMs (134).

Hence, for human behavior changes, joint activities between Universities, Research Centers, Health Ministries, and others will be legally necessary constitution of Departments that could be responsible by outline joint projects and approaches for health promotion through seminars, and lectures to implement in schools (Primary and Secondary), enterprises and families to promote healthy food cooking, sale, and intake to pave the way to reduce obesity and its RMDs prevalence (140-144). 


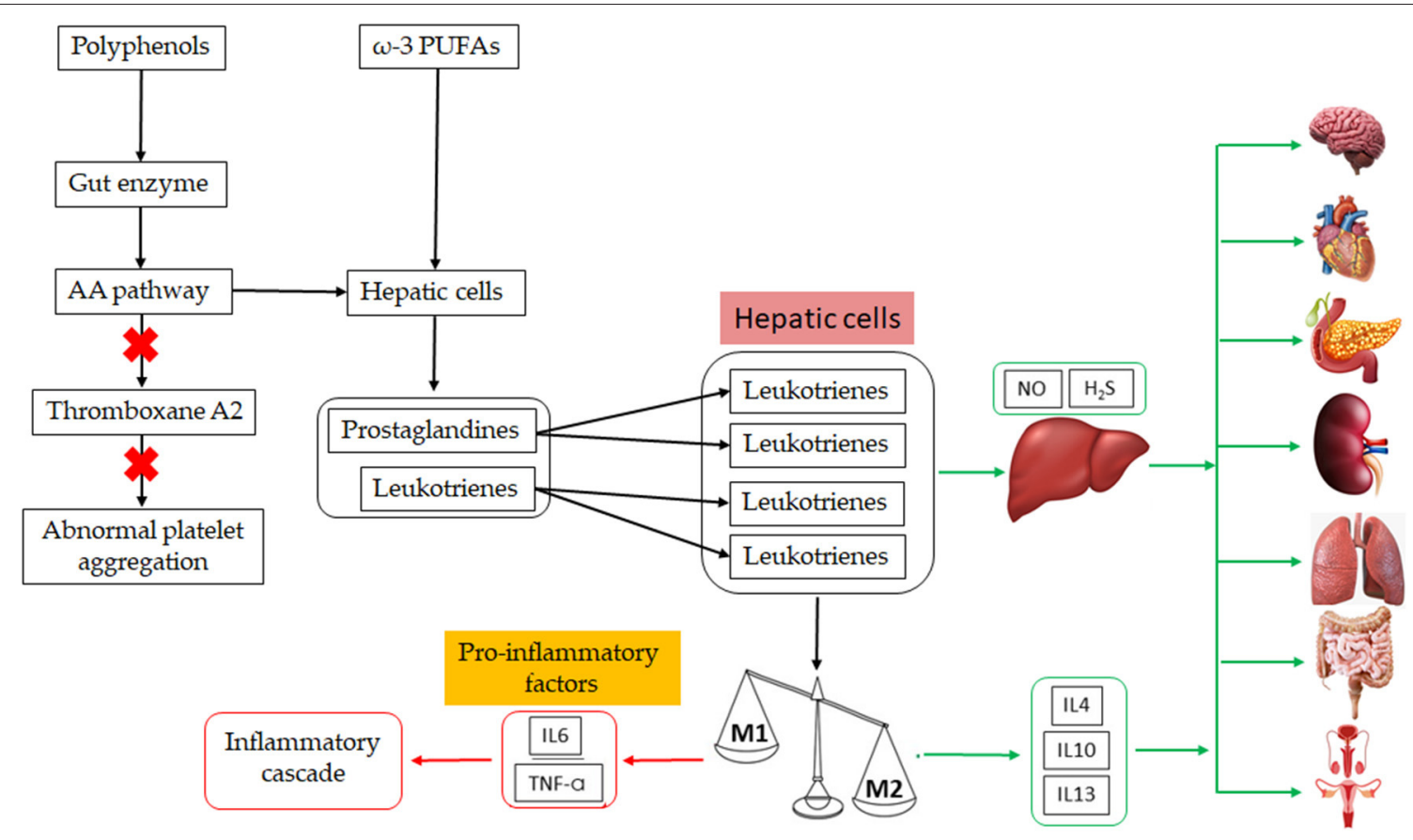

FIGURE 3 | Mechanism involved in an inflammatory condition and its resolution using $\omega$-3 PUFAs and polyphenols dietary. The action of products from PUFAs metabolization (hepatic biosynthesis or tissue under inflammation), lipoxins, resolvins, protectins, and maresins on macrophage profile change and the endothelial cells. As a result, there are anti-inflammatory interleukins, nitric oxide (NO) and hydrogen sulfite $\left(\mathrm{H}_{2} \mathrm{~S}\right)$ being produced, which will provide the resolution and tissue regeneration. Products from polyphenols metabolization are also connected with this anti-inflammatory pathway to several organs in the body. M1, type 1 macrophages; M2, type 2 macrophages; IL, interleukin; TNF- $\alpha$, tumor necrosis factor-alpha. Green lines mean resolution of the inflammatory process and red lines mean the uncontrolled inflammatory process leading to an inflammatory cascade.

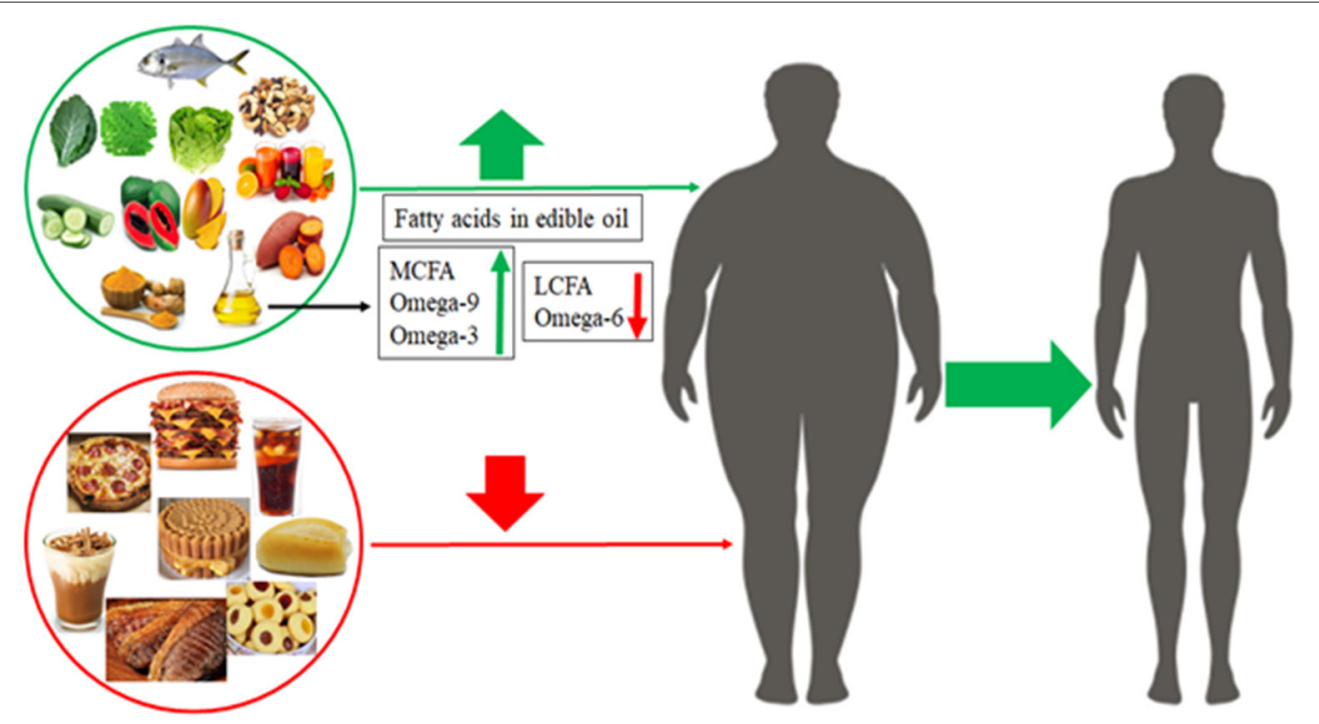

FIGURE 4 | Healthy food (green line) intake reduce obesity to normal conditions, while unhealthy food (red line) conduces to obesity and its related metabolic diseases.

\section{CONCLUSION}

The consumption of vegetables, fruits, seed and fish and/or supplements rich in polyphenols and $\omega-3$ PUFAs is widely correlated with reducing of obesity and its related metabolic diseases prevalence. Thus, for behavior change, it is necessary to draw out a joint projects of research institutions and the Health Ministries to schools, enterprises and families to promote healthy food intake to reduce obesity and its related metabolic diseases. 


\section{AUTHOR CONTRIBUTIONS}

TS, DM, VZ-P, DB, AP, and RG conceptualized the topic, researched and analyzed the literature, wrote the manuscript, and including interpretation. $\mathrm{PF}, \mathrm{GM}, \mathrm{PH}, \mathrm{MV}, \mathrm{RF}, \mathrm{EC}$, and VN contributed with draft and interpretation and revised the manuscript critically for intellectual content. All authors have read and approved the final version of the manuscript, ensure the accuracy and integrity of the work, and agree to be accountable for all appearance.

\section{FUNDING}

This research was funded by Federal University of Mato Grosso do Sul (UFMS) and Coordination of Higher Education

\section{REFERENCES}

1. Rogero MM, Calder P. Obesity, inflammation, toll-like receptor 4 and fatty acids. Nutrients. (2018) 10:432. doi: 10.3390/nu10040432

2. Lyons CL, Kennedy EB, Roche HM. Metabolic inflammationdifferential modulation by dietary constituents. Nutrients. (2016) 8:247. doi: $10.3390 /$ nu8050247

3. Figueiredo PS, Inada AC, Marcelino G, Cardozo CML, Freitas KC, Guimarães RCA, et al. Fatty acids consumption: the role metabolic aspects involved in obesity and its associated disorders. Nutrients. (2017) 9:1158. doi: 10.3390/nu9101158

4. Machate DJ, Figueiredo PS, Marcelino G, Guimarães RCA, Hiane PA, Bogo D, et al. Fatty acid diets: regulation of gut microbiota composition and obesity and its related metabolic dysbiosis. Int J Mol Sci. (2020) 21:4093. doi: 10.3390/ijms21114093

5. World Health Organization. Health Diet. (2021). Available online at: https://www.who.int/news-room/fact-sheets/detail/healthy-diet\#: \:text= Eating\%20at\%20least $\% 20400 \% 20$ g, aily\%20intake\%20of\%20dietary\%20fibre (accessed August 4, 2021).

6. Mafort TT, Rufino R, Costa CH, Lopes AJ. Obesity: systemic and pulmonary complications, biochemical abnormalities, and impairment of lung function. Multidiscip Respir Med. (2016) 11:28. doi: 10.1186/s40248-016-0066-Z

7. Kris-Etherton PM, Grieger JA, Etherton TD. Dietary reference intakes for DHA and EPA. Prostaglandins Leukot Essent Fatty Acids. (2009) 81:99104. doi: 10.1016/j.plefa.2009.05.011

8. Slavin JL, Lloyd B. Health benefits of fruits and vegetables. Adv Nutr. (2012) 3:506-16. doi: 10.3945/an.112.002154

9. Hogan S, Canning C, Sun S, Sun X, Zhou K. Effects of grape pomace antioxidant extract on oxidative stress and inflammation in diet induced obese mice. J Agric Food Chem. (2010) 58:11250-6. doi: 10.1021/jf102759e

10. Van Hul M, Geurts L, Plovier H, Druart C, Everard A, Stahlman $\mathrm{M}$, et al. Reduced obesity, diabetes, and steatosis upon cinnamon and grape pomace are associated with changes in gut microbiota and markers of gut barrier. Am J Physiol Endocrinol Metab. (2018) 314:E33452. doi: 10.1152/ajpendo.00107.2017

11. Violi F, Loffredo L, Pigatelli P, Angelico F, Bartimoccia S, Nocella C, et al. Extra virgin olive oil use is associated with improved post-prandial blood glucose and LDL cholesterol in healthy subjects. Nutr Diabetes. (2015) 5:e172. doi: 10.1038/nutd.2015.23

12. Carnevale R, Loffredo L, Del Ben M, Angelico F, Nocella C, Petruccioli A, et al. Extra virgin olive oil improves post-prandial glycemic and lipid profile in patients with impaired fasting glucose. Clin Nutr. (2017) 36:7827. doi: 10.1016/j.clnu.2016.05.016

13. Chuang CC, McIntosh MK. Potential mechanisms by which polyphenolrich grapes prevent obesity-mediated inflammation and metabolic diseases. Annu Rev Nutr. (2011) 31:155-76. doi: 10.1146/annurev-nutr-072610145149
Personnel Improvement (CAPES)-Portaria 2016/2018. This study was financed in part by the CAPES-finance code 001 . The study was also supported by research grants from the National Council for Scientific and Technological Development (Conselho Nacional de Desenvolvimento Científico e Tecnológico-CNPq).

\section{ACKNOWLEDGMENTS}

We thank the Graduate Program in Material Sciences, Graduate Program in Biotechnology and Biodiversity, and the Graduate Program in Health and Development in the Central-West Region, Federal University of Mato Grosso do Sul-UFMS for support.
14. Méndez L, Medina I. Polyphenols and fish oils for improving metabolic health: a revision of the recent evidence for their combined nutraceutical effects. Molecules. (2021) 26:2438. doi: 10.3390/molecules26092438

15. Pagliaro M, Pizzone DM, Scurria A, Lino C, Paone E, Mauriello F, et al. Sustainably sourced olive polyphenols and ômega-3 marine lipids: a synergy fostering public health. ACS Food Sci Technol. (2021) 1:13945. doi: 10.1021/acsfoodscitech.0c00082

16. Pan H, Gao Y, Tu Y. Mechanisms of body weight reduction by black tea polyphenols. Molecules. (2016) 21:1659. doi: 10.3390/molecules21121659

17. Manach C, Mazur A, Scalbert A. Polyphenols and prevention of cardiovascular diseases. Curr Opin Lipidol. (2005) 16:7784. doi: 10.1097/00041433-200502000-00013

18. Hodgson JM, Croft KD. Tea flavonoids and cardiovascular health. Mol Aspects Med. (2010) 31:495-502. doi: 10.1016/j.mam.2010.09.004

19. Cheng YC, Sheen JM, Hu WL, Hung YC. Polyphenols and oxidative stress in atherosclerosis-related ischemic heart disease and stroke. Oxid Med Cell Longev. (2017) 2017:8526438. doi: 10.1155/2017/8526438

20. Giglio RV, Patti AM, Cicero AFG, Luppi G, Rizzo M, Toth PP, et al. Polyphenols: potential use in the prevention and treatment of cardiovascular diseases. Curr Pharm Des. (2018) 24:239-58. doi: 10.2174/1381612824666180130112652

21. Tang GY, Meng X, Gan RY, Zhao CN, Liu Q, Feng YB, et al. Health functions and related molecular mechanisms of tea components: an update review. Int J Mol Sci. (2019) 20:6196. doi: 10.3390/ijms20246196

22. Laraia BA, Leak TM, Tester JM, Leung CW. Biobehavioral factors that shape nutritional in low-income populations: a narrative review. Am J Prev Med. (2017) 52:S118-26. doi: 10.1016/j.amepre.2016.08.003

23. Jones NRV, Conklin AI, Suhrcke M, Monsivais P. The growing price gap between more and less healthy foods: analysis of a novel longitudinal UK dataset. PLoS ONE. (2014) 9:e109343. doi: 10.1371/journal.pone.0109343

24. Seguin R, Connor L, Nelson M, LaCroix A, Eldridge G. Understanding barriers and facilitators to healthy eating and active living in rural communities. J Nutr Metab. (2014) 2014:146502. doi: 10.1155/2014/146502

25. Fard NA, Morales GF, Mejova Y, Schifanella R. On the interplay between educational attainment and nutrition: a spatially-aware perspective. EPJ Data Sci. (2021) 10:18. doi: 10.1140/epjds/s13688-021-00273-y

26. Zhu F, Du B, Zheng L, Li J. Advance on the bioactivity and potential applications of dietary fibre from grape pomace. Food Chem. (2015) 186:20712. doi: 10.1016/j.foodchem.2014.07.057

27. Ribeiro LF, Ribani RH, Francisco TMG, Soares AA, Pontarolo R, Haminiuk CWI. Profile of bioactive compounds from grape pomace (Vitis vinifera and Vitis labrusca) by spectrophotometric, chromatographic and spectral analyses. J Chromatogr B Analyt Technol Biomed Life Sci. (2015) 1007:7280. doi: 10.1016/j.jchromb.2015.11.005

28. Rasines-Perea Z, Teissedre PL. Grape polyphenols' effects in human cardiovascular diseases and diabetes. Molecules. (2017) 22:68. doi: 10.3390/molecules22010068 
29. Talhaoui N, Gómez-Caravaca AM, León L, De la Rosa R, FernándezGutiérrez A, Segura-Carretero A. From olive fruits to olive oil: phenolic compound transfer in six different olive cultivars grown under the same agronomical conditions. Int J Mol Sci. (2016) 17:337. doi: 10.3390/ijms17030337

30. Dal S, Sigrist S. The protective effect of antioxidants consumption on diabetes and vascular complications. Diseases. (2016) 4:24. doi: 10.3390/diseases4030024

31. Lamien-Meda A, Lamien CE, Compaoré MMY, Meda RNT, Kiendrebeogo M, Zeba B, et al. Polyphenol content and antioxidant activity of fourteen wild edible fruits from Burkina Faso. Molecules. (2008) 13:58194. doi: 10.3390/molecules13030581

32. Shan S, Huang X, Shah MH, Abbasi AM. Evaluation of polyphenolics content and antioxidant activity in edible wild fruits. Biomed Res Int. (2019) 2019:1381989. doi: 10.1155/2019/1381989

33. Pandey KB, Rizvi SI. Plant polyphenols as dietary antioxidants in human health and disease. Oxid Med Cell Longev. (2009) 2:2708. doi: 10.4161/oxim.2.5.9498

34. Kumar V, Sharma A, Kohli SK, Bali S, Sharma M, Kumar R, et al. Differential distribution of polyphenols in plants using multivariate techniques. Biotechnol Res Innov. (2019) 3:1-21. doi: 10.1016/j.biori.2019.03.001

35. Serreli G, Deiana M. Biological relevance of extra virgin olive oil polyphenols metabolites. Antioxidants. (2018) 7:170. doi: 10.3390/antiox7120170

36. Lima GPP, Vianello F, Corrêa CR, Campos RAS, Borguini MG. Polyphenols in fruits and vegetables and its effect on human health. Food Nutr Sci. (2014) 5:1065-82. doi: 10.4236/fns.2014.511117

37. Xu DP, Li Y, Meng X, Zhou T, Zhou Y, Zheng J, et al. Natural antioxidants in foods and medicinal plants: Extraction, assessment and resources. Int J Mol Sci. (2017) 18:96. doi: 10.3390/ijms18010096

38. Wei Z, Luo J, Huang Y, Guo W, Zhang Y, Guan H, et al. Profile of polyphenol compounds of five muscadine grapes cultivated in the United States and in newly adapted locations in China. Int J Mol Sci. (2017) 18:631. doi: 10.3390/ijms18030631

39. Liu C, Guo Y, Sun L, Lai X, Li Q, Zhang W, et al. Six types of tea reduce high-fat diet-induced fat accumulation in mice by increasing lipid metabolism and suppressing inflammation. Food Funct. (2019) 10:206174. doi: 10.1039/C8FO02334D

40. Chuang CC, Shen W, Chen H, Xie G, Jia W, Chung S, et al. Differential effects of grape powder and its extract on glucose tolerance and chronic inflammation in high-fat-fed obese mice. J Agric Food Chem. (2012) 60:12458-68. doi: 10.1021/jf3028107

41. Pascual-Serrano A, Arola-Arnal A, Suárez-García S, Bravo FI, Suárez M, Arola L, et al. Grape seed proanthocyanidin supplementation reduces adipocyte size and increases adipocyte number in obese rats. Int $J$ Obes. (2017) 41:1246-55. doi: 10.1038/ijo.2017.90

42. Elmhdwi MF, Elaali NMS, Mohamed NN, Muktar MA, Buzgeia NB. Anti-diabetic activity of methanolic extract of grape seeds in alloxan induced diabetic rats. Agr Res Tech. (2017) 6:555699. doi: 10.19080/ARTOAJ.2017.06.555699

43. Ballard CR, Santos EF, Dubois MJ, Pilon G, Cazarin CBB, Maróstica Junior $\mathrm{MR}$, et al. Two polyphenol-rich Brazilian fruit extracts protect from dietinduced obesity and hepatic steatosis in mice. Food Funct. (2020) 11:880010. doi: 10.1039/D0FO01912G

44. Ebaid H, Bashandy SAE, Alhazza IM, Hassan I, Al-Tamimi J. Efficacy of a methanolic extract of Adansonia digitata leaf in alleviating hyperglycemia, hyperlipidemia, and oxidative stress of diabetic rats. Biomed Res Int. (2019) 2019:2835152. doi: 10.1155/2019/2835152

45. Vazquez A, Sanchez-Rodriguez E, Vargas F, Montoro-Molina S, Romero M, Espejo-Calvo JA, et al. Cardioprotective effect of a virgin olive oil enriched with bioactive compounds in spontaneously hypertensive rats. Nutrients. (2019) 11:1728. doi: 10.3390/nu11081728

46. Jurado-Ruiz E, Álvarez-Amor L, Varela LM, Bern,á, G., Parra-Camacho MS, Oliveira-Lopez MJ, et al. Extra virgin olive oil diet intervention improves insulin resistance and islet performance in diet-induced diabetes in mice. Sci Rep. (2019) 9:11311. doi: 10.1038/s41598-019-47904-z

47. Weisberg SP, Leibel R, Tortoriello DV. Dietary curcumin significantly improves obesity- associated inflammation and diabetes in mouse models of diabesity. Endocrinology. (2008) 149:3549-58. doi: 10.1210/en.2008-0262
48. Seo KI, Lee J, Choi RY, Lee HI, Lee JH, Jeong YK, et al. Anti-obesity and antiinsulin resistance effects of tomato vinegar beverage in diet-induced obese mice. Food Funct. (2014) 5:1579-86. doi: 10.1039/c4fo00135d

49. Oliveira PR, Costa CA, Bem GF, Cordeiro VSC, Santos IB, Carvalho LCRM, et al. Euterpe oleracea Mart.-Derived polyphenols protect mice from diet-induced obesity and fatty liver by regulating hepatic lipogenesis and cholesterol excretion. PLoS ONE. (2015) 10:e0143721. doi: 10.1371/journal.pone.0143721

50. Panchal SK, Poudyal H, Waanders J, Brown L. Coffee extract attenuates changes in cardiovascular and hepatic structure and function without decreasing obesity in high-carbohydrate, high-fat diet-fed male rats. J Nutr. (2012) 142:690-7. doi: 10.3945/jn.111.153577

51. Boqué N, Iglesia R, Garza AL, Milagro FI, Olivares M, Bañuelos O, et al. Prevention of diet-induced obesity by apple polyphenols in Wister rats through regulation of adipocyte gene expression and DNA methylation patterns. Mol Nutr Food Res. (2013) 57:1473-8. doi: 10.1002/mnfr.20120 0686

52. Azman KF, Amom Z, Azlan A, Esa NM, Ali RM, Shah ZM, et al. Antiobesity effect of Tamarindus indica L. pulp aqueous extract in high-fat diet-induced obese rats. J Nat Med. (2011) 66:333-42. doi: 10.1007/s11418-011-0597-8

53. Aranaz P, Navarro-Herrera D, Romo-Hualde A, Zabala M, López-Yoldi M, González-Ferrero C, et al. Broccoli extract improves high fat diet-induced obesity, steatosis and glucose intolerance in Wistar rats. J Funct Foods. (2019) 59:319-28. doi: 10.1016/j.jff.2019.05.054

54. Lambert JD, Sang, S, Yang CS. Possible controversy over dietary polyphenols: benefits vs risks. Chem Res Toxicol. (2007) 20:583-5. doi: 10.1021/tx7000515

55. Mennen LI, Walker R, Bennetau-Pelissero C, Scalbert A. Risks and safety of polyphenols consumption. Am J Clin Nutr. (2005) 81:326S-9S. doi: 10.1093/ajcn/81.1.326S

56. Ofosu FK, Daliri EBM, Elahi F, Chelliah R, Lee BH, Oh DH. New insights on the use of polyphenols as natural preservatives and their emerging safety concerns. Front Sustain Food Syst. (2020) 4:525810. doi: 10.3389/fsufs.2020.525810

57. Wang S, Moustaid-Moussa N, Chen L, Mo H, Shastri A, Su R, et al. Novel insights of dietary polyphenols and obesity. J Nutr Biochem. (2014) 25:1-18. doi: 10.1016/j.jnutbio.2013.09.001

58. Zunino SJ, Peerson JM, Freytag TL, Breksa AP, Bonnel EL, Woodhouse LR, et al. Dietary grape powder increases IL- $1 \beta$ and IL- 6 production by lipopolysaccharide- activated monocytes and reduces plasma concentrations of large LDL and large LDL-cholesterol particles in obese humans. Br J Nutr. (2014) 112:369-80. doi: 10.1017/S0007114514000890

59. Chew B, Mathison B, Kimble L, McKay D, Kaspar K, Khoo C, et al. Chronic consumption of a low calorie, high polyphenol cranberry beverage attenuates inflammation and improves glucoregulation and HDL cholesterol in healthy overweight humans: a ranamized controlled trial. Eur J Nutr. (2019) 58:122335. doi: 10.1007/s00394-018-1643-z

60. Álvarez-Pérez J, Sánchez-Villegas A, Díaz-Benítez EM, Ruano-Rodríguez C, Corella D, Martínez-González AM, et al. Influence of a Mediterranean dietary pattern on body fat distribution: results of the PREDIMEDCanarias intervention randomized trial. J Am Coll Nutr. (2016) 35:56880. doi: $10.1080 / 07315724.2015 .1102102$

61. Lum T, Connolly M, Marx A, Beidler J, Hooshmand S, Kern M, et al. Effects of fresh watermelon consumption on the acute satiety response and cardiometabolic risk factors in overweight and obese adults. Nutrients. (2019) 11:595. doi: 10.3390/nu11030595

62. Balsan G, Pellanda LC, Sausen G, Galarraga T, Zaffari D, Pontin B, et al. Effect of yerba mate and green tea on paraoxonase and leptin levels in patients affected by overweight or obesity and dyslipidemia: a randomized clinical trial. Nutr J. (2019) 18:5. doi: 10.1186/s12937-018-0426-y

63. Herranz-López M, Olivares-Vicente M, Boix-Castejón M, Caturla $\mathrm{N}$, Roche E, Micol V. Differential effects of a combination of Hibiscus sabdariffa and Lippia citriodora polyphenols in overweight/obese subjects: a randomized controlled trial. Sci Rep. (2019) 9:2999. doi: 10.1038/s41598-01939159-5

64. Azzini E, Venneria E, Ciarapica D, Foddai MS, Intorre F, Zaccaria M, et al. Effect of red orange juice consumption on body composition and nutritional status in overweight/obese female: a pilot study. Oxid Med Cell Longev. (2017) 2017:1672567. doi: 10.1155/2017/1672567 
65. Zunino SJ, Parelman MA, Freytag TL, Stephensen CB, Kelley DS, Mackey $\mathrm{BE}$, et al. Effects of dietary strawberry powder on blood lipids and inflammatory markers in obese human subjects. Br J Nutr. (2012) 108:9009. doi: 10.1017/S0007114511006027

66. Roussel AM, Hininger I, Benaraba R, Ziegenfuss TN, Anderson RA. Antioxidant effects of a cinnamon extract in people with impaired fasting glucose that are overweight or obese. $\mathrm{J} A \mathrm{~m}$ Coll Nutr. (2009) 28:16-21. doi: 10.1080/07315724.2009.107 19756

67. Leverrier A, Daguet D, Calame W, Dhoye P, Kodimule SP. Helianthus annuus seed extract affects weight and body composition of healthy obese adults during 12 weeks of consumption: a randomized, double-blind, placebo-controlled pilot study. Nutrients. (2019) 11:1080. doi: 10.3390/nu11051080

68. Saini RK, Shetty N, Giridhar P. GC-FID/MS Analysis of fatty acids in Indian cultivars of Moringa oleifera: potential sources of PUFA. J Am Oil Chem Soc. (2014) 91:1029-34. doi: 10.1007/s11746-014-2439-9

69. Saini RK, Shang XM, Ko EY, Choi JH, Kim D, Keum YS. Characterization of nutritionally important phytoconstituents in minimally processed ready-toeat baby-leaf vegetables using HPLC-DAD and GC-MS. J Food Meas Charact. (2016) 10:341-9. doi: 10.1007/s11694-016-9312-5

70. Kim DE, Shang X, Assefa AD, Keum YS, Saini RK. Metabolite profiling of green, green/red, and red lettuce cultivars: variation in health beneficial compounds and antioxidant potential. Food Res Int. (2018) 105:36170. doi: 10.1016/j.foodres.2017.11.028

71. Hernández-Martínez M, Gallardo-Velázquez T, Osorio-Revilla G, Castañeda-Pérez E, Uribe-Hernández K. Characterization of Mexican fishes according to fatty acid profile and fat nutritional indices. Int J Food Prop. (2016) 19:1401-12. doi: 10.1080/10942912.2015.1079787

72. Sharafi Y, Majidi MM, Goli SAH, Rashidi F. Oil content and fatty acids composition in Brassica species. Int J Food Prop. (2015) 18:214554. doi: 10.1080/10942912.2014.968284

73. Pereira H, Barreira L, Figueiredo F, Custódio L, Vizetto-Duarte C, Polo $\mathrm{C}$, et al. Polyunsaturated fatty acids of marine macroalgae: potential for nutritional and pharmaceutical applications. Mar Drugs. (2012) 10:192035. doi: $10.3390 / \mathrm{md} 10091920$

74. Ramos Filho MM, Ramos MIL, Hiane PA, Souza EMT. Nutritional value of seven freshwater fish species from the Brazilian Pantanal. J Am Oil Chem Soc. (2010) 87:1461-7. doi: 10.1007/s11746-010-1639-1

75. Halinski LP, Topolewska A, Rynkowska A, Mika A, Urasinska M, Czerski M, et al. Impact of plant domestication on selected nutrient and anti-nutrient compounds in Solanaceae with edible leaves (Solanum spp.). Genet Rosour Crop Evol. (2019) 66:89-103. doi: 10.1007/s10722-018-0699-1

76. Ljubojevic D, Trbovic D, Lujic J, Bjelic-Cabrilo O, Kostic D, Novaov N, et al. Fatty acid composition of fishes from inland waters. Bulg J Agric Sci. (2013) 19:62-71.

77. Peltomaa E, Johnson MD, Taipale SJ. Marine cryptophytes are great sources of EPA and DHA. Mar Drugs. (2017) 16:3. doi: 10.3390/md16010003

78. Saini RK, Keum YS. Omega-3 and omega- 6 polyunsaturated fatty acids: dietary sources, metabolism, and significance-a review. Life Sci. (2018) 203:255-67. doi: 10.1016/j.lfs.2018.04.049

79. Shahidi F, Ambigaipalan P. Omega-3 polyunsaturated fatty acids and their health benefits. Annu Rev Food Sci Technol. (2018) 9:34581. doi: 10.1146/annurev-food-111317-095850

80. Burns-Whitmore B, Froyen E, Heskey C, Parker T, Pablo GS. Alphalinolenic and linoleic fatty acids in the vegan diet: do they require dietary reference intake/adequate intake special consideration? Nutrients. (2019) 11:2365. doi: 10.3390/nu11102365

81. Bazinet RP, Layé S. Polyunsaturated fatty acids and their metabolites in brain function and disease. Nat Rev Neurosci. (2014) 15:77185. doi: $10.1038 / \mathrm{nrn} 3820$

82. Long EK, Picklo MJ Sr. Trans-4-hydroxy-2-hexenal, a product of n-3 fatty acid peroxidation: make some room HNE. Free Radic Biol Med. (2010) 49:1-8. doi: 10.1016/j.freeradbiomed.2010.03.015

83. Tanaka R, Shigeta K, Sugiura Y, Hatate H, Matsushita T. Accumulation of hydroxyl lipids and 4-hydroxy-2-hexenal in live fish infected with fish diseases. Lipids. (2014) 49:385-96. doi: 10.1007/s11745-013-3875-2
84. Tao L. Oxidation of polyunsaturated fatty acids and its impact on food quality and human health. Adv Food Technol Nutr Sci Open J. (2015) 1:135-42. doi: 10.17140/AFTNSOJ-1-123

85. Ward PA. Resolvins on the way to resolution. J Exp Med. (2015) 212:1142. doi: 10.1084/jem.2128insight4

86. Zhang J, Freund MA, Culler MD, Yang R, Chen PB, Park Y, et al. How to stabilize $\omega-3$ polyunsaturated fatty acids (PUFAs) in an animal feeding study?-Effects of the temperature, oxygen level, and antioxidant on oxidative stability of $\omega$-3 PUFAs in a mouse diet. J Agric Food Chem. (2020) 68:114653. doi: 10.1021/acs.jafc.9b08298

87. Halvorsen BL, Blomhoff R. Determination of lipid oxidation products in vegetable oils and marine omega-3 supplements. Food Nutr Res. (2011) 55:5792. doi: 10.3402/fnr.v55i0.5792

88. Bastías JM, Balladares P, Acuña S, Quevedo R, Muñoz O. Determining effect of different cooking methods on the nutritional composition of salmon (Salmo salar) and Chilean jack mackerel (Trachurus murphyi) fillets. PLoS ONE. (2017) 12:e0180993. doi: 10.1371/journal.pone.0180993

89. Leung KS, Galano JM, Durand T, Lee JCY. Profiling of omegapolyunsaturated fatty acids and their oxidized products in salmon after different cooking methods. Antioxidants. (2018) 7:96. doi: 10.3390/antiox7080096

90. Damanik M, Murkovic M. The stability of palm oils during heating in a rancimat. Eur Food Res Tech. (2018) 244:12939. doi: 10.1007/s00217-018-3044-1

91. Hassanien MMM, Abdel-Razek AG, Rudzinska M, Siger A, Ratusz K, Przybylski R. Phytochemical contents and oxidative stability of oils from non-traditional sources. Eur J Lipid Sci Tech. (2014) 116:156371. doi: 10.1002/ejlt.201300475

92. Shadyro O, Sosnovskaya A, Edimecheva I. Effect of biologically active substances on oxidative stability. J Food Sci Technol. (2020) 57:24352. doi: 10.1007/s13197-019-04054-4

93. Pérez-Matute P, Pérez-Echarri N, Martínez JA, Marti A, Moreno-Aliaga MJ. Eicosapentaenoic acid actions on adiposity and insulin resistance in control and high-fat-fed rats: Role of apoptosis, adiponectin and tumour necrosis factor- $\alpha$. Brit J Nutr. (2007) 97:389-98. doi: 10.1017/S0007114507207627

94. Hassanali Z, Ametaj BN, Field CJ, Proctor SD, Vine DF. Dietary supplementation of n-3 PUFA reduces weight gain and improves postprandial lipaemia and the associated inflammatory response in the obese JCR:LA-cp rat. Diabetes Obes Metab. (2010) 12:139-47. doi: 10.1111/j.1463-1326.2009.01130.x

95. Castro GS, Deminice R, Simões-Ambrosio LMC, Calder PC, Jordão AA, Vannucchi H. Dietary docosahexaenoic acid and eicosapentaenoic acid influence liver triacylglycerol and insulin resistance in rats fed a highfructose diet. Mar Drugs. (2015) 13:1864-81. doi: 10.3390/md13041864

96. Shang T, Liu L, Zhou J, Zhang M, Hu Q, Fang M, et al. Protective effects of various ratios of DHA/EPA supplementation on highfat diet-induced liver damage in mice. Lipids Health Dis. (2017) 16:65. doi: 10.1186/s12944-017-0461-2

97. Huber J, Löffler M, Bilban M, Reimers M, Kadl A, Todoric J, et al. Prevention of high-fat diet-induced adipose tissue remodeling in obese diabetic mice by n-3 polyunsaturated fatty acids. Inter J Obes. (2007) 31:1004-13. doi: 10.1038/sj.ijo.0803511

98. Pauter AM, Fischer AW, Bengtsson T, Asadi A, Talamonti E, Jacobsson A. Synergistic effects of DHA and sucrose on body weight gain in PUFAdeficient Elovl2-/-mice. Nutrients. (2019) 11:852. doi: 10.3390/nu11040852

99. Soni N, Ross AB, Scheers N, Nookaew I, Gabrielsson BG, Sandberg AS. The omega-3 fatty acids EPA and DHA, as a part of a murine high-fat diet, reduced lipid accumulation in brown and white adipose tissues. Int J Mol Sci. (2019) 20:5895. doi: 10.3390/ijms20235895

100. Liu HQ, Qiu Y, Mu Y, Zhang XJ, Liu L, Hou XH, et al. A high ratio of dietary n-3/n-6 polyunsaturated fatty acids improves obesity-linked inflammation and insulin resistance through suppressing activation of TLR4 in SD rats. Nutr Res. (2013) 33:849-58. doi: 10.1016/j.nutres.2013.07.004

101. Demizieux L, Piscitelli F, Troy-Fioramonti S, Iannotti FA, Borrino S, Gresti J, et al. Early low-fat diet enriched with linolenic acid reduces liver endocannabinoid tone and improves late glycemic control after a high-fat diet challenge in mice. Diabetes. (2016) 65:1824-37. doi: 10.2337/db15-1279 
102. Tyagi A, Kumar U, Reddy S, Santosh VS, Mohammed SB, Ehtesham NZ, et al. Attenuation of colonic inflammation by partial replacement of dietary linoleic acid with $\alpha$-linolenic acid in a rat model of inflammatory bowel disease. BJN. (2012) 18:1612-22. doi: 10.1017/S0007114511007197

103. Mayer C, Côme M, Ulmann L, Zittelli GC, Faraloni C, Hassan N, et al. Preventive effects of the marine microalga Phaeodactylum triconutum, used as a food supplement, on risk factors associated with metabolic syndrome in Wistar rats. Nutrients. (2019) 11:1069. doi: 10.3390/nu11051069

104. Chewcharat A, Chewcharat P, Rutirapong A, Papatheodorou S. The effects of omega-3 fatty acids on diabetic nephropathy: a meta-analysis of randomized controlled trials. PLoS ONE. (2020) 15:e0228315. doi: 10.1371/journal.pone.0228315

105. Chen C, Yu X, Shao S. Effects of omega-3 fatty acid supplementation on glucose control and lipid levels in type 2 diabetes: a meta-analysis. PLoS ONE. (2015) 10:e0139565. doi: 10.1371/journal.pone.0139565

106. Du S, Jin J, Fang W, and Su Q. Does fish oil have an anti-obesity effect in overweight/obese adults? A meta-analysis of randomized controlled trials. PLoS ONE. (2015) 10:e0142652. doi: 10.1371/journal.pone.0142652

107. Root M, Collier SR, Zwetsloot KA, West KL, McGinn MC. A randomized trial of fish oil omega-3 fatty acids on arterial health, inflammation, and metabolic syndrome in a young healthy population. Nutr J. (2013) 12:40. doi: 10.1186/1475-2891-12-40

108. Abdelhamid AS, Brown TJ, Brainard JS, Biswas P, Thorpe GC, Moore HJ, et al. Omega-3 fatty acids for the primary and secondary prevention of cardiovascular disease. Cochrane Database Syst Rev. (2018) 3:CD003177. doi: 10.1002/14651858.CD003177.pub4

109. Curfman G. Do omega-3 fatty acids benefit health? J Am Med Assoc. (2020) 324:2280-1. doi: 10.1001/jama.2020.22898

110. Weylandt K, Serini S, Chen YQ, Su HM, Lim K, Cittadini A, et al. Omega3 polyunsaturated fatty acids: the way forward in times of mixed evidence. Biomed Res Int. (2015) 2015:43109. doi: 10.1155/2015/143109

111. Mani UV, Mani I, Biswas M, Kumar SN. An open-label study on the effect of flax seed powder (Linum usitatissimum) supplementation in the management of diabetes mellitus. J Diet Suppl. (2011) 8:25765. doi: 10.3109/19390211.2011.593615

112. Zhao G, Etherton TD, Martin KR, West SG, Gillies PJ, Kris-Etherton PM. Dietary alpha-linolenic acid reduces inflammatory and lipid cardiovascular risk factors in hypercholesterolemic men and women. J Nutr. (2004) 134:2997-2004. doi: 10.1093/jn/134.11.2991

113. Maki KC, Van Elswyk ME, McCarthy D, Hess SP, Veith PE, Bell M, et al. Lipid responses to a dietary docosahexaenoic acid supplement in men and women with below average levels of high density lipoprotein cholesterol. J Am Coll Nutr. (2005) 24:189-99. doi: 10.1080/07315724.2005.10719465

114. Sanders TAB, Gleason K, Griffin B, Miller GJ. Influence of an algal triacylglycerol containing docosahexaenoic acid (22:6n-3) and docosapentaenoico acid (22:5n-6) on cardiovascular risk factors in healthy men and women. Brit J Nutr. (2006) 95:525-31. doi: 10.1079/BJN20051658

115. Satoh N, Shimatsu A, Kotani K, Sakane N, Yamada K, Suganami T, et al. Purified eicosapentaenoic acid reduces small dense LDL, remnant lipoprotein particles, and C-reactive protein in metabolic syndrome. Diabetes Care. (2007) 30:144-6. doi: 10.2337/dc06-1179

116. Yokoyama M, Origasa H, Matsuzaki M, Matsuzawa Y, Saito Y, Ishikawa Y, et al. Effects of eicosapentaenoic acid on major coronary events in hypercholesterolaemic patients (JELIS): a randomised open-label, blinded endpoint analysis. Lancet. (2007) 369:1090-8. doi: 10.1016/S0140-6736(07)60527-3

117. Tanaka K, Ishikawa Y, Yokoyama M, Origasa H, Matsuzaki M, Saito Y, et al. Reduction in the recurrence of stroke by eicosapentaenoic acid for hypercholesterolemic patients: subanalysis of the JELIS trial. Stroke. (2008) 39:2052-8. doi: 10.1161/STROKEAHA.107.509455

118. Haghiac M, Yang XH, Presley L, Smith S, Dettelback S, Minium J, et al. Dietary omega-3 fatty acid supplementation reduces inflammation in obese pregnant women: a randomized double-blind controlled clinical trial. PLoS ONE. (2015) 10:e0137309. doi: 10.1371/journal.pone.0137309

119. Elulu MS, Khaza'ai H, Patimah I, Rahmat A, Abed Y. Effect of long chain omega-3 polyunsaturated fatty acids on inflammation and metabolic markers in hypertensive and/or diabetic obese adults: a randomized controlled trial. Food Nutr Res. (2016) 60:29268. doi: 10.3402/fnr.v60.29268
120. Karnik S, Kanekar A. Childhood obesity: a global public health crisis. Int $J$ Prev Med. (2012) 3:1-7. doi: 10.1201/b18227-3

121. Boateng GO, Adams EA, Boateng MO, Luginaah IN, Taabazuing MM. Obesity and the burden of health risks among the elderly in Ghana: a population study. PLoS ONE. (2017) 12:e186947. doi: 10.1371/journal.pone.0186947

122. Calder PC. Omega-3 fatty acids and inflammatory processes: from molecules to man. Biochem Soc Trans. (2017) 45:1105-15. doi: 10.1042/BST20160474

123. Bocellino M, D’Angelo S. Anti-obesity effects of polyphenol intake: current status and future possibilities. Int J Mol Sci. (2020) 21:5642. doi: 10.3390/ijms21165642

124. Duvall MG, Levy BD. DHA- and EPA-derived resolvins, protectins, and maresins in airway inflammation. Eur J Pharmacol. (2016) 785:14455. doi: 10.1016/j.ejphar.2015.11.001

125. Kwon Y. Immuno-resolving ability of resolvins, protectins, and maresins derived fromomega-3 fatty acids in metabolic syndrome. Mol Nutr Food Res. (2020) 64:e1900824. doi: 10.1002/mnfr.201900824

126. Kawabata K, Yoshioka Y, Terao J. Role of intestinal microbiota in the bioavailability and physiological functions of dietary polyphenols. Molecules. (2019) 24:370. doi: 10.3390/molecules24020370

127. Yahfoufi N, Alsadi N, Jambi M, Matar C. The immunomodulatory and anti- inflammatory role of polyphenols. Nutrients. (2018) 10:1618. doi: 10.3390/nu10111618

128. Van Meer F, Charbonnier L, Smeets PM. Food decisionmaking: effects of weight status and age. Curr Diab Rep. (2016) 16:84. doi: 10.1007/s11892-016-0773-Z

129. Beslay M, Srour B, Méjean C, Allès B, Fiolet T, Debras C, et al. Ultra-processed food intake in association with BMI change and risk of overweight and obesity: a prospective analysis of the French NutriNetSanté cohort. PLoS Med. (2020) 17:e1003256. doi: 10.1371/journal.pmed. 1003256

130. Kumoro AC, Alhanif M, Wardhani DH. A critical review on tropical fruits seeds as prospective sources of nutritional and bioactive compounds for functional foods development: a case of Indonesian exotic fruits. Int J Food Sci. (2020) 2020:4051475. doi: 10.1155/2020/4051475

131. Torres-León C, Ramírez-Guzman N, Londoño-Hernandez L, MartinezMedina GA, Díaz-Herrera R, Navarro-Macias V, et al. Food waste and byproducts: an opportunity to minimize malnutrition and hunger in development countries. Front Sustain Food Syst. (2018) 2:52. doi: $10.3389 /$ fsufs. 2018.00052

132. Guasch-Ferré $\mathrm{M}, \mathrm{Hu}$ FB. Are fruit juices just as unhealthy as sugar-sweetened beverages? J Am Med Assoc Netw Open. (2019) 2:e193109. doi: 10.1001/jamanetworkopen.2019.3109

133. World Health Organization (2021). Global Health Observatory (GHO). Available online at: http://www.who.int/gho/ncd/risk_factors/overweight_ obesity/obesity_adults/en/ (accessed August 20, 2021).

134. Hosomi R, Yoshida M, Fukunaga K. Seafood consumption and components for health. Glob J Health Sci. (2012) 4:72-86. doi: 10.5539/gjhs.v4n3p72

135. Rejman K, Górska-Warsewicz H, Kaczorowska J, Laskowski W. Nutritional significance of fruit and fruit products in the average polish diet. Nutrients. (2021) 13:2079. doi: 10.3390/nu13062079

136. Melse-Boonstra A. Bioavailability of micronutrients from nutrient-dense whole foods: zooming in on dairy, vegetable, and fruits. Front Nutr. (2020) 7:101. doi: 10.3389/fnut.2020.00101

137. Balami S, Sharma A, Karn R. Significance of nutritional value of fish for human health. Malays $J$ Halal Res. (2019) 2:32-4. doi: 10.2478/mjhr-2019-0012

138. Kearney J. Food consumption trends and drives. Phil Trans R Soc B Biol Sci. (2010) 365:2793-807. doi: 10.1098/rstb.2010.0149

139. Sproesser G, Ruby MB, Arbit N, Akotia CS, Alvarenga MS, Bhangaokar R, et al. Understanding traditional and modern eating: the TEP10 framework. BMC Public Health. (2019) 19:1606. doi: 10.1186/s12889-019-7844-4

140. Zhang P, Wang R, Gao C, Jiang L, Lv X, Song Y, et al. Prevalence of central obesity among adults with normal BMI and its association with metabolic diseases in Northeast China. PLoS ONE. (2016) 11:e0160402. doi: 10.1371/journal.pone.0160402

141. Saklayen MG. The global epidemic of the metabolic syndrome. Curr Hypertens Rep. (2018) 20:12. doi: 10.1007/s11906-018-0812-z 
142. Motevalli M, Drenowartz C, Tanous DR, Khan NA. Management of childhood obesity-time to shift from generalized to personalized intervention strategies. Nutrients. (2021) 13:1200. doi: 10.3390/nu130 41200

143. Popkin BM, Adair LS, Ng SW. Now and then: The global nutrition transition: the pandemic of obesity in developing countries. Nutr Rev. (2012) 70:321. doi: 10.1111/j.1753-4887.2011.00456.x

144. Arshad F, Umbreen H, Aslam I, Hameed A, Aftab K, Al-Qahtani $\mathrm{WH}$, et al. Therapeutic role of mango peels in management of dyslipidemia and oxidative stress in obese females. Biomed Res Inter. (2021) 2021:3094571. doi: 10.1155/2021/3094571

Conflict of Interest: The authors declare that the research was conducted in the absence of any commercial or financial relationships that could be construed as a potential conflict of interest.
Publisher's Note: All claims expressed in this article are solely those of the authors and do not necessarily represent those of their affiliated organizations, or those of the publisher, the editors and the reviewers. Any product that may be evaluated in this article, or claim that may be made by its manufacturer, is not guaranteed or endorsed by the publisher.

Copyright (C) 2022 Siroma, Machate, Zorgetto-Pinheiro, Figueiredo, Marcelino, Hiane, Bogo, Pott, Cury, Guimarães, Vilela, Ferreira and Nascimento. This is an open-access article distributed under the terms of the Creative Commons Attribution License (CC BY). The use, distribution or reproduction in other forums is permitted, provided the original author(s) and the copyright owner(s) are credited and that the original publication in this journal is cited, in accordance with accepted academic practice. No use, distribution or reproduction is permitted which does not comply with these terms. 